\title{
Early Holocene aeolian sediments in southwestern Crete-preliminary results
}

\author{
Fabian Kirsten $^{1,2}\left(\mathbb{0} \cdot\right.$ Alexander Fülling $^{3} \cdot$ Susann Heinrich ${ }^{4} \cdot$ Birgit Schneider $^{1} \cdot$ Jürgen Heinrich ${ }^{2}$
}

Received: 26 February 2021 / Revised: 16 July 2021 / Accepted: 17 July 2021 / Published online: 27 July 2021

(c) The Author(s) 2021

\begin{abstract}
The soilscapes along the southern and western coast of Crete (Greece) are dominated by coarse-grained reddish-brown slope sediments whose natural (pre-anthropogenic) configuration and properties are difficult to reconstruct due to the long history of intense land use. As a consequence, datable terrestrial sediment archives of pre-anthropogenic genesis are scarce. We present preliminary results of a study performed on an accumulation within an alluvial fan south of Stomio Bay in southwestern Crete. The studied profile is located in a small depression and is composed of a sequence of sandy to silty yellowish-brown calcareous sediments overlying coarse-grained slope sediments, including a fossil topsoil horizon. Based on macroscopic, micromorphological, geochemical, geophysical and mineralogical analysis, we interpret the fine-grained sediments to have a local aeolian origin. OSL dating indicates a final deposition phase during the early Holocene. Considering the scarcity of early Holocene terrestrial archives in Crete, the analysed profile provides valuable data for the reconstruction of landscape dynamics and paleoecological conditions as well as soil-sediment configurations during this time period. Additional research is needed to address the specific source area(s) as well as the ages of the deposition of slope sediments and formation of the fossil topsoil.
\end{abstract}

Keywords Aeolian sediments $\cdot$ Fossil soil $\cdot$ Early Holocene $\cdot$ Crete $\cdot$ Eastern Mediterranean

\section{Introduction}

While soils of the Mediterranean area have been extensively investigated (Brunnacker 1979; Durn 2003; Fedoroff and Courty 2013; Yaalon 1997), in the case of Crete (Greece), the parent materials of Holocene soils and their distribution among different landscape units have scarcely been examined. Generally, the current soil cover on Crete is considered to be the shallow remnant of formerly complete soil profiles

Fabian Kirsten

Fabian.kirsten@fu-berlin.de

1 Department of Earth Sciences, Physical Geography, Freie Universität Berlin, Malteserstraße 74-100, Haus H, 12249 Berlin, Germany

2 Institute for Geography, Leipzig University, Johannisallee 19a, 04103 Leipzig, Germany

3 Sedimentary Geology and Quaternary Research, Albert-Ludwigs-University Freiburg, Albertstr. 23b, 79104 Freiburg, Germany

4 Max-Planck-Institute for Evolutionary Anthropology, Deutscher Platz 6, 04103 Leipzig, Germany that have been degraded by anthropogenic land use throughout the last millenia (Rackham and Moody 1996) as in many other Mediterranean landscapes (Butzer 2005; Dusar et al. 2011). A few publications address the distribution and properties of soils on Crete (Boix et al. 1995; Lydakis-Simantiris et al. 2005; Moraetis et al. 2006, 2015; Nevros and Zvorykin 1939; Yassoglou et al. 2017), while many studies focused on geomorphological-sedimentological aspects (Poser 1957; Hempel 1991; Mouslopoulou et al. 2017; Pope et al. 2016; Scheffers and Scheffers 2007; Werner et al. 2019) and geoarchaeological questions (Morris 2002; Rackham and Moody 1996; Siart 2010; Siart et al. 2010; Siart and Eitel 2013; Strasser et al. 2010). However, since numerical dating has rarely been implemented in geomorphological and pedological studies on Crete, there is little information regarding the genesis and the age of soil parent materials.

Coarse-grained reddish-brown sediments have been identified in karstic features such as poljes and dolines (Egli 1993; Siart et al. 2010) in a range of altitudes from the coastline to the high mountains of Crete. Rivers along the steep southern and western coast have formed large alluvial fans that mostly consist of sediments rich in coarse 
fragments, while purely fine-grained sediments are rare (Pope et al. 2016; Mouslopoulou et al. 2017). The development of these alluvial fans is likely due to the steep relief, the long history of intensive land use and regular torrential runoff events. However, in major sediment sinks such as the Messara Plain in Central Crete or river beds along the less steep northern coast, fine-grained sediments are more frequent (Ghilardi et al. 2018, 2019). Landscapes made up of Tertiary marls (mostly in tectonic trenches) have been intensively used for agriculture for millennia and have subsequently been subjected to severe soil erosion. Furthermore, the deposition of very fine-grained brownish-red dust was observed by the authors on several occasions. This important input of North African provenance into most of Crete's soils has been extensively studied and described in recent decades (Christidis et al. 2010; Pye 1992; Nihlén and Mattsson 1989; Nihlén and Solyom 1986, 1989; Nihlén et al. 1995; Rapp and Nihlén 1986). Late-Quaternary slope and sediment dynamics in the mountain ranges and along the northern coast of Crete have been studied by Hempel (1982, 1984, 1987, 1991). As a result of intensive land use since Minoan times, most Cretan landscapes have been severely modified, hindering the reconstruction of natural/pre-anthropogenic conditions and soil-/sediment-distribution. Existing paleoecological studies (Bottema 1980; Bottema and Sarpaki 2003; Ghilardi et al. 2018, 2019; Jouffroy-Bapicot et al. 2016; Lespez et al. 2003; Theodorakopoulou et al. 2012) are mainly focused on the middle to late Holocene records due to the scarcity of well-preserved terrestrial deposits dating to the Pleistocene-Holocene transition.

While different geomorphological aspects of Crete have gained much attention, there is a research gap regarding geomorphological processes and paleoenvironmental conditions during the late Pleistocene and early Holocene. The resultant research gap is all the more important as studies of adjacent areas like the Peloponnes (Heymann et al. 2013; Weiberg et al. 2016) or paleoclimatic and paleoecological studies concerning the entire eastern Mediterranean have shown that the early Holocene climate was affected by strong spatio-temporal variations in temperature and aridity (Dusar et al. 2011; Robinson et al. 2006; Roberts et al. 2011).

During a field campaign in the spring of 2019, a deposit of yellowish-brown well sorted fine-grained (sandy to silty) material was observed in a large exposure created as a result of the construction of a large water storage basin near the coastline of southwestern Crete. The profile (Chriso 1) offers a unique example of fine-grained deposits free of coarse fragments, rarely described for Crete. The sediment characteristics and their stratigraphic position do not suggest the presence of fluvially reworked marls, but rather an aeolian origin.

The main research questions that we address in this study are as follows:
- Which geomorphological processes resulted in the studied sedimentary record?

- What are the potential source areas of the sediments?

- What can be deducted in regard to regional landscape and sediment dynamics during the early Holocene?

\section{Geographical setting}

\subsection{Geological and geomorphological context of the Chriso 1 profile}

Chriso 1 is located near the village and monastery of Chrisokalitissa at the southwestern tip of Crete at an altitude of $95 \mathrm{~m}$ (measured at the base of the profile) and at a distance of approximately $1500 \mathrm{~m}$ from to the current shoreline (see Fig. 1b).

Due to Crete's geotectonic position at the contact of the African and Eurasian tectonic plates, it can be described as a nappe pile consisting of different sedimentary and metamorphic rock units, formed before and during the Alpine subduction and collision processes (Eocene to Early Miocene) (Martha et al. 2017). The different napes are not necessarily represented by the exact same geological units over the entire island, and their original stratigraphic positions in many cases have been altered as the result of tectonic processes (Fassoulas 2001).

The mountain ranges stretching on a north-south axis to the east of the coastal plain and reaching about $600 \mathrm{~m}$ a.s.l. are composed of limestones and dolomites of the upper Triassic (Fig. 2: $\mathrm{T}_{\mathrm{s}} \mathrm{Ji}, \mathrm{k}, \mathrm{d}$ ), a mixed formation of the Phyllite-Quarzite (PQ)-unit ( $\mathrm{ph} / \mathrm{sch} / \mathrm{mr}$ ) from the Upper Carboniferous and schists ("Stavros-Seli") intercalated with evaporites (anhydrite-gypsum) from the Upper Triassic. According to the geological map 1:50 000 (IGME 2002), an overthrust and a fault are located very close to the sampled profile. About $2 \mathrm{~km}$ to the north of the profile, Stomio River, one of the largest rivers of western Crete, enters the Mediterranean Sea at Stomio Bay. The river is approximately $10 \mathrm{~km}$ long and drains a watershed of about $25 \mathrm{~km}^{2}$. Its catchment area consists of bedrocks belonging to the mixed formation, the "Aghios Dikeos quartzites" and "Stavros-Seli schists" of the Phyllite-Quartzite-unit in the upper reaches, while the lower reaches are dominated by limestones, dolomites and evaporites belonging to the autochthonous series of the Upper Triassic.

The coastal plain to the north and south of Stomio Bay, a former marine abrasion platform (Kelletat 1979), is made up of marly Neogene limestones $(\mathrm{Ng})$ that have been covered by large Pleistocene alluvial fans (SC-CS) (Fig. 2). The Chriso 1 profile is located in a small depression on the alluvial fan (the fan deposits are, however, not represented in the geological map at the sampling location). 


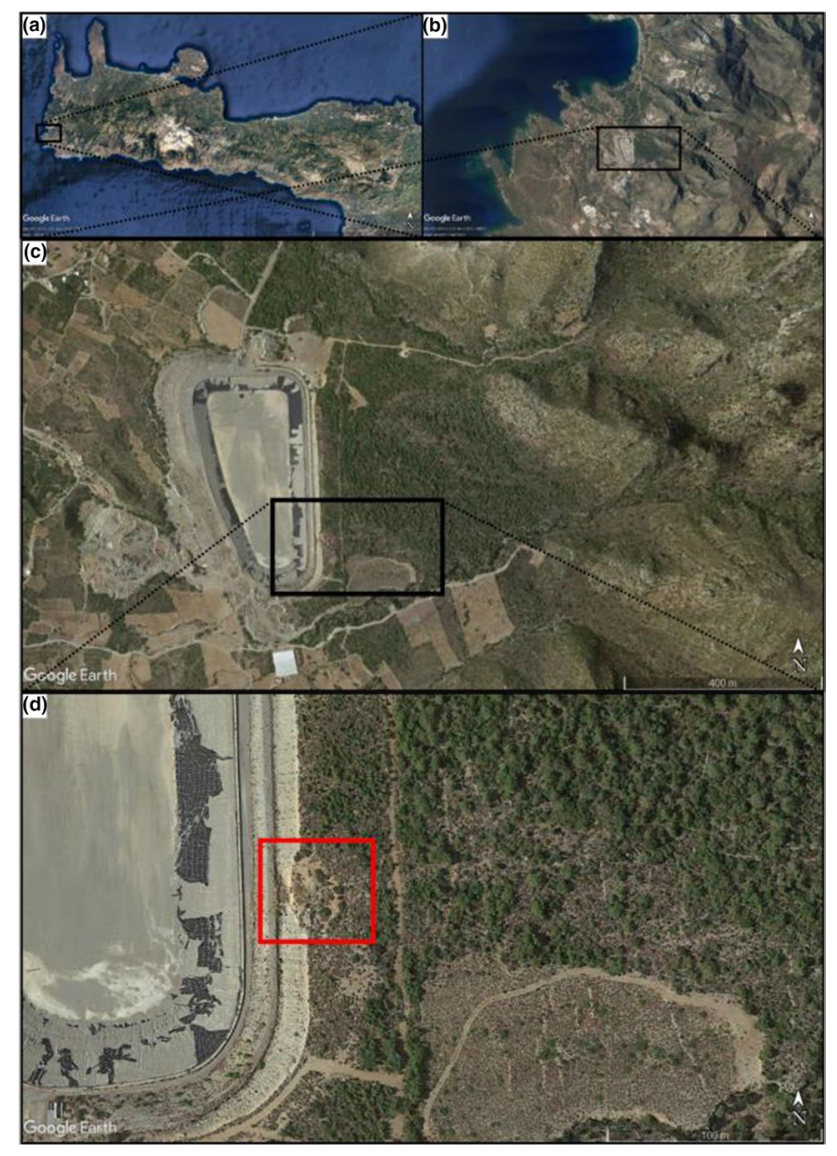

Fig. 1 Location of Chriso 1 in southwestern Crete (a) General location of study area at the southwestern tip of Crete (b) Location of abandoned water storage pond south of Stomio Bay (c) Location of abandoned water storage pond within consolidated alluvial fan sediments (d) Location of small depression containing the sampled profile (red square) at the south-eastern edge of abandoned water storage pond (Google Earth 2021, satellite images recorded in 9/2018, Image Landsat/Copernicus, (2021 CNES/Airbus)

While the coastal plain contains round karstic features, such as dolines and small poljes that formed through the dissolution of (Neogene) limestones, a topographic map (1:50 000) of the German Military from 1941 (Gen. St. d. H. Abt. f. Kr. Kart. und Verm. Wes.) depicts several linear drainage pathways but no circular hollows (dolines) for the surroundings of the profile (Fig. 3). Therefore, the small depression containing the sampled sediments was interpreted as a head of a small, dry valley developed on the alluvial fan. During the early 1940s, the study area was already under agriculture use, as documented in the map by several rectangular outlines of fields. The area continued to be under agriculture use at least into the 1970s, as could be confirmed by high-resolution declassified military satellite images from 1974 (KH-9 mission, Earth Resources Observation And Science (EROS) Center 2017, image not displayed).
A detailed reconstruction of the terrain surrounding the sampling location was limited by the construction of the large water storage pond. Furthermore, the area around the abandoned water pond has been subject to intense land levelling for greenhouses, olive orchards and infrastructure, making the reconstruction of pre-modern, let alone preanthropogenic, surface features virtually impossible.

\subsection{Quaternary deposits in the study area}

Based on our field observations we have concluded that reddish-brown slope debris/scree, rich in coarse fragments, is the dominating sediment type on slopes among different geological units, altitudes and landscape positions along the mountain ranges of southern and western Crete. Our observations on Crete suggest that regolith containing considerable amounts of dust, represents the main parent material for soils on slopes in most landscape units. This dust was transported downslope over a long-range by reoccurring single events of heavy rainfall.

Apart from coarse slope sediments, only a few other sediment types were observed during field campaigns. Near the current shoreline, up to about $100 \mathrm{~m}$ a.s.l., young sandy aeolian sediments occur as dunes or sandy contributions in near-surface soil horizons.

\subsection{Modern and Late-Quaternary climate}

The climate on Crete is characterized by warm summers and cool, humid winters. The coastal plain of south-western Crete, south of Stomio Bay (see Fig. 1a, b), has a mean annual temperature of about $19^{\circ} \mathrm{C}$ and a mean annual precipitation between 450 and $500 \mathrm{~mm}$ (Hellenic National Meteorological Service 2020).

Throughout the late Quaternary, the climate in the eastern Mediterranean and on Crete underwent major fluctuations that have been reconstructed from terrestrial and marine archives. The late Pleistocene in the eastern Mediterranean and the Aegean Sea was cooler and more arid than today, especially but not exclusively during the Last Glacial Maximum (LGM) and the Younger Dryas (Dusar et al. 2011; Geraga et al. 2000, 2010; Gvirtzman and Wieder 2001; Heymann et al. 2013; Robinson et al. 2006; Rossignol-Strick et al. 1992; Triantaphyllou et al. 2009).

Increased sedimentation in the eastern Mediterranean during the early Holocene has been attributed to an overall climatic change towards wetter conditions soon before deciduous forests began to cover landscapes and reversed this trend (Dusar et al. 2011). This general climatic pattern is supported by Hempel (1982) based on his findings in northern Crete.

However, there still is uncertainty regarding the timing and distribution patterns of the increase in temperatures and 


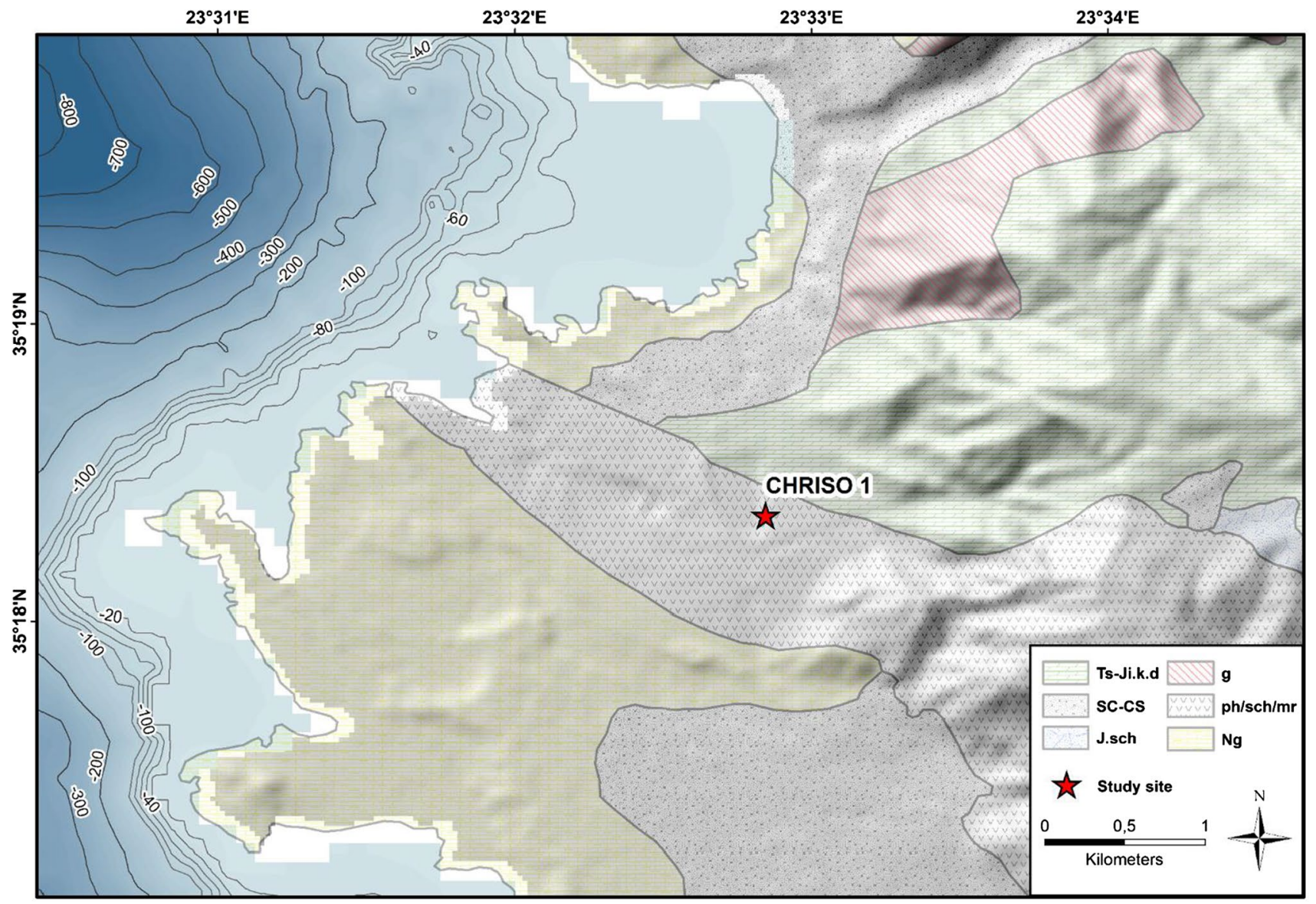

Fig. 2 Bathymetry near the coastline of southwestern Crete and land topography (hillshade) overlain by main geological formations. The location of Chriso 1 profile is marked by a red star. (Coordinates: GCS WGS 84). Bathymetrie data: EMODnet Bathymetric Grid (2018) (resolution approx. $115 \mathrm{~m}$, bilinear interpolation) (white tiles: no data). Relief Hillshade (background): DEM Copernicus GLO30 (resolution $30 \mathrm{~m}$ ). Geology: Geological Map of Greece 1:50 000 Palaeochora Sheet, IGME 2002 (digitalized). Ts-Ji.k.d: Upper Tri-

precipitation as well as the related changes in vegetation cover during the early Holocene (Brunovic et al. 2020). Sea level fluctuations on the shores of Crete during the late Holocene amounting to several meters were mainly driven by tectonic events, while only minor eustatic sea level changes occurred (Mourtzas et al. 2016). However, during the late Pleistocene, the sea level was considerably lower than today due to climate. Lambeck and Purcell (2005) calculated a relative sea level difference of $-140 \mathrm{~m}$ around $20 \mathrm{ka} \mathrm{BP}$ and $-60 \mathrm{~m}$ at $12 \mathrm{ka} \mathrm{BP}$ around Crete compared to the current sea level. At $6 \mathrm{ka} \mathrm{BP}$, sea-level was only about $5 \mathrm{~m}$ below its current level (Lambeck and Purcell 2005). Based on a global sea-level curve by Siddall et al. (2003) for the last glacial cycles, at $12 \mathrm{ka} \mathrm{BP}$, the relative sea-level was between -80 and $-100 \mathrm{~m}$, followed by a very quick rise in sea level that occurred between 11 and $9 \mathrm{ka} \mathrm{BP}$, bringing it to about $20 \mathrm{~m}$ below current levels (Mouslopolou et al. 2017). assic (recrystallized limestones and dolomites). SC-CS: Holocene talus cones and scree (carbonate and phyllitic rubles of various sizes, mixed with terra rossa, loose and locally consolidated). $\mathrm{J}_{\text {sch }}$ : Schists, recrystallized limestones, quartzites. g: Evaporites (anhydrite-gypsum). $\mathrm{ph} / \mathrm{sch} / \mathrm{mr}$ : Mixed formation of Phyllite-Quartzite-Series (chloritoid schists, quartzites and platy marbles). $\mathrm{Ng}$ : Neogene formations Tortonian-Pliocene (marly limestones, clayed-marley formations with silt and sand intercalations)

\section{Material and methods}

\subsection{Sampling}

A sediment/soil-profile (Chriso 1, 35.306278 ${ }^{\circ} \mathrm{N} 23.547274^{\circ}$ E) was sampled near the village and monastery of Chrisokalitissa at the southwestern tip of Crete. The profile is located at $95 \mathrm{~m}$ a.s.l. at the edge of an exposure within a small depression (eastern wall of an abandoned water storage basin built around 2000). The depression is about $30 \mathrm{~m}$ long from north to south and reaches its maximum depth of about $10 \mathrm{~m}$ below the surrounding surface in the centre of the depression where sampling was performed. The main stratigraphic units are illustrated in Fig. 4.

Due to the steep slope, the uppermost part of the profile (unit 1, unconsolidated coarse slope debris on top of finegrained layers) could not be accessed and sampled. 


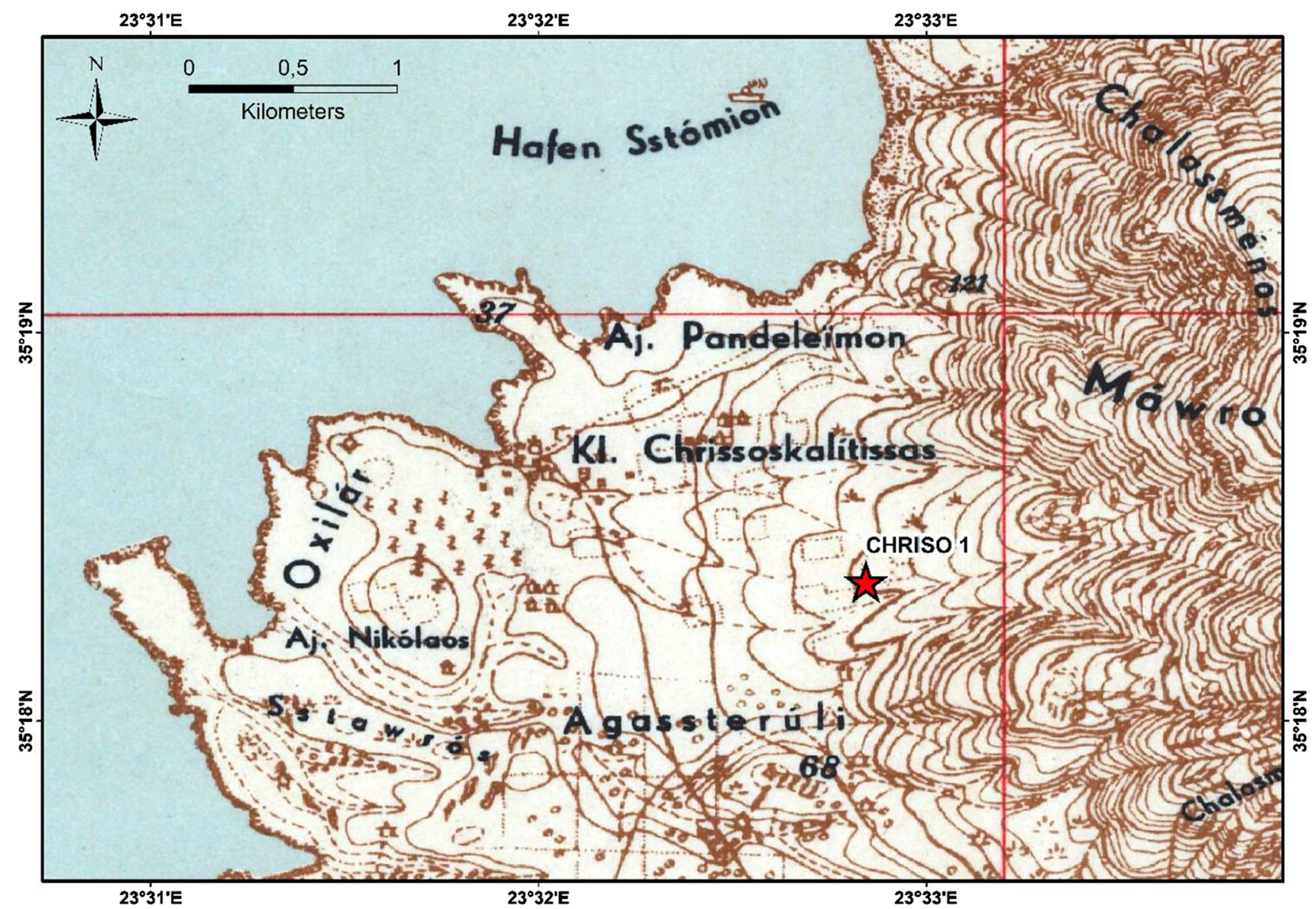

Fig. 3 Location of profile Chriso 1 (red star) with respect to historical map from 1941 (modified from: Deutsche Heereskarte Griechenland 1:50 000, Blatt 4 Kastelli, 1941), contour intervals 10 m (Coordinates: GCS WGS 84)

In order to characterize the main stratigraphic units (2 and 3), five bulk samples (loose sediment) were taken (Fig. 5).

At the same depths as samples $2-1$ and 2-3, undisturbed samples for luminescence dating were taken by hammering steel tubes horizontally into the freshly cleaned profile walls (CR-1 and CR-2, Fig. 5). Additionally, three undisturbed samples (Mimo 2-1, Mimo 2-2, Mimo 2-3) using Kubiena boxes (following Goldberg and Macphail 2003) were taken for thin sections and micromorphological analysis (Fig. 5).

\subsection{Sample preparation and analysis}

Bulk samples were air-dried and sieved to separate coarse fragment $(>2 \mathrm{~mm})$ from the fine fraction. A portion of the fine $(<2 \mathrm{~mm})$ fraction was ground in a planetary ball mill PM 200 (Retsch) for $10 \mathrm{~min}$ to achieve a required grain size of $<30 \mu \mathrm{m}$ needed for X-Ray-Diffraction (XRD), X-RayFluorescence (XRF), Total Organic Carbon (TOC) and magnetic susceptibility measurements (see below).

\subsubsection{Grain size distribution}

$10 \mathrm{~g}$ of samples were left in $50 \mathrm{ml} 35 \%$ hydrogen peroxide $\left(\mathrm{H}_{2} \mathrm{O}_{2}\right)$ and heated to remove organic matter. Afterwards, the samples were dispersed using $10 \mathrm{ml} 0.4 \mathrm{~N}$ sodium pyrophosphate solution $\left(\mathrm{Na}_{4} \mathrm{P}_{2} \mathrm{O}_{7}\right)$ and ultrasonic treatment for 45 min. $\mathrm{CaCO}_{3}$ was not removed following the recommendation by Lucke and Schmidt (2015), as primary carbonatic particles are needed for sedimentological interpretation.

Grain size classes of the fine-earth fraction were calculated by combining the results of dry-sieving for the sand fraction (63-2000 $\mu \mathrm{m})$ and X-ray granulometry (XRG) using a Sedigraph III 5120 (Micromeritics) for the clay and silt fraction $(<63 \mu \mathrm{m})$. The combined data, displayed as $\%$, have not been mathematically corrected for small errors (as the original result of analysis) that may amount to a maximum of $1 \%$ of the total sum.

Within the sand fraction, three discrete grain-size classes were distinguished by dry sieving: coarse sand "cS" $(2000-630 \mu \mathrm{m})$, medium sand "mS" (630-200 $\mu \mathrm{m})$ and fine sand "fS" (200-63 $\mu \mathrm{m})$. Within the clay and silt fractions 


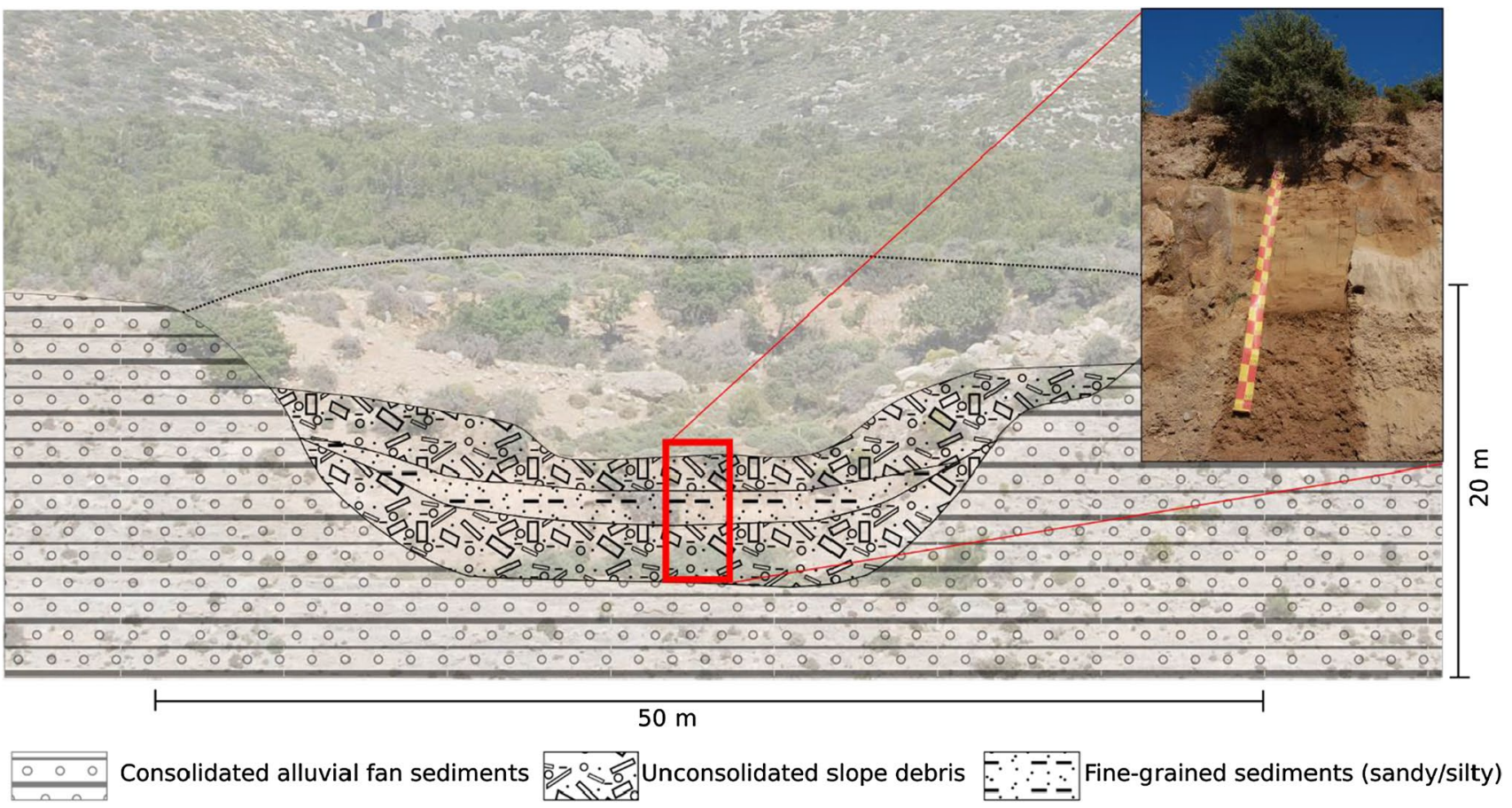

Fig. 4 Stratigraphy of the sampling site (red rectangle marks position of sampled profile, see photograph in upper right corner)

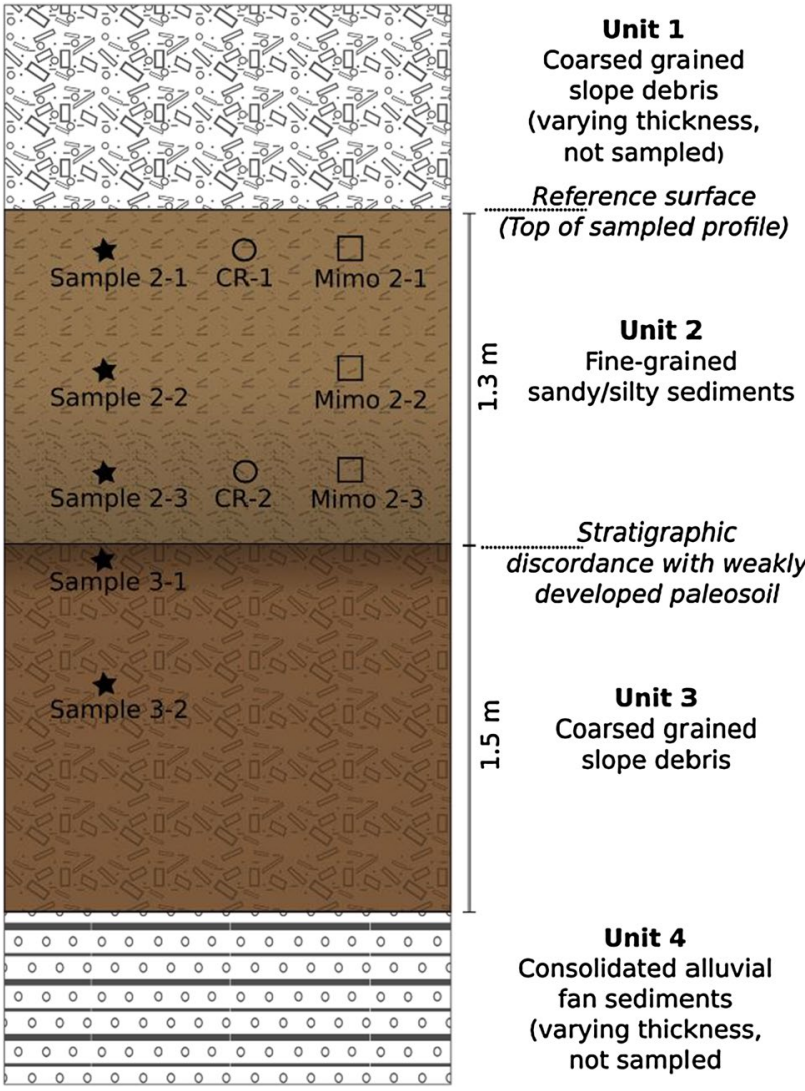

Fig. 5 Sketch of the sampled profile with stratigraphic units and sampled locations
$(<63 \mu \mathrm{m})$, six discrete grain size classes were distinguished based on sedigraph measurements: coarse silt "cSi" (63-20 $\mu \mathrm{m})$, medium silt "mSi" $(20-6.3 \mu \mathrm{m})$, fine silt "fSi" $(6.3-2.0 \mu \mathrm{m})$, coarse clay "cC" $(2.00-0.6 \mu \mathrm{m})$, medium clay "mC" $(0.63-0.2 \mu \mathrm{m})$ and fine clay "fC" $(<0.2 \mu \mathrm{m})$.

Furthermore, data from sedigraph measurements distinguishing 101 single fractions (measurement intervals) between 0.2 and $63 \mu \mathrm{m}$ were used in order to identify the detailed distribution of grain sizes as well as characteristic peaks within this specific grain size range. All values are given as mass-percentages of grains.

\subsubsection{Element contents and Fe-weathering-index}

For the determination of total element contents, $32 \mathrm{~mm}$ pellets were produced by mixing and pressing $8 \mathrm{~g}$ of the ground subsample material with 2 g CEREOX Licowax prior to measurement with a Spectro Xepos-X-ray fluorescence spectrometer.

Contents of iron oxides were determined with oxalate (DIN ISO 19,684-1 1977) $\left(\mathrm{Fe}_{\mathrm{o}}\right)$ and dithionite (Mehra and Jackson 1960, DIN ISO 19,684-1 1977) ( $\left.\mathrm{Fe}_{\mathrm{d}}\right)$ extraction, respectively. Measurement was performed with an AAS PERKIN ELMER PinAAcle 900 T.

Using the analytically determined contents of $\mathrm{Fe}_{\mathrm{t}}, \mathrm{Fe}_{\mathrm{o}}$, $\mathrm{Fe}_{\mathrm{d}}$ and clay, the Fe-weathering-index $=\left(\mathrm{Fe}_{\mathrm{d}}-\mathrm{Fe}_{\mathrm{o}}\right) /\left(\mathrm{Fe}_{\mathrm{t}} /\right.$ clay) was calculated following Kehl et al. (2005) and Zöller 
and Nehring (2002) for the determination of weathering intensities.

\subsubsection{Munsell colours}

Soil colours were determined under standardized moist conditions in the laboratory, based on the Munsell soil colour chart.

\subsubsection{PH}

$\mathrm{PH}$ values were measured in a $0.01 \mathrm{M} \mathrm{CaCl}_{2}$ suspension following DIN ISO 10,390 with a ratio of 1:2.5 (soil/water).

\subsubsection{Total organic carbon (TOC) and total inorganic carbon (TIC)}

Total organic carbon (TOC) content was measured by katalytic oxidation at $680^{\circ} \mathrm{C}$ and subsequent NDIR-detection using a TOC-L Shimadzu device with $50 \mathrm{mg}$ of the ground sample. Prior to analysis, inorganic carbon was removed by adding $1 \mathrm{~N} \mathrm{HCl}$ (DIN EN 15,936:2020-08-Entwurf). Total carbon (TC) was measured by dry combustion at $1200^{\circ} \mathrm{C}$, using a Vario EL cube elemental analyzer. Total inorganic carbon (TIC) was calculated by subtracting TOC from TC.

\subsubsection{Mineralogy}

Mineralogical composition was determined using X-ray powder diffraction (XRD) of the ground subsamples. Diffraction data were recorded on a PANalytical Empyrean diffractometer using $\mathrm{CuK} \alpha$ radiation $(\lambda=1.54060 \AA)$ at $40 \mathrm{kV}$ and a tube current of $40 \mathrm{~mA}$. Unoriented samples were scanned on a rotating stage at a step size of $0.013^{\circ} 2 \theta$ in the range $5-70^{\circ} 2 \theta$. Mineral quantification was performed with the Rietveld refinement function of the BGMN/Profex v4.3.0 (Döbelin and Kleeberg 2015).

\subsubsection{Magnetic susceptibility}

Magnetic properties were analysed using $10 \mathrm{~cm}^{3}$ of ground subsamples, densely packed in rectangular plastic boxes. Volume-specific magnetic susceptibility $(\kappa)$ was measured at low $\left(0.465 \mathrm{kHz}, \kappa_{\mathrm{LF}}\right)$ and high $\left(4.65 \mathrm{kHz}, \kappa_{\mathrm{HF}}\right)$ frequencies using a Bartington MS3 magnetic susceptibility meter equipped with a MS2B dual frequency sensor. The following parameters were calculated from these measurements:

1. Mass-specific magnetic susceptibility $(\chi)\left(10^{-8} \mathrm{~m}^{3} / \mathrm{kg}\right)$ was obtained by relating $\kappa_{\mathrm{LF}}$ to the mass of each sample.

2. Frequency-dependent magnetic susceptibility $\left(\chi_{\mathrm{fd}}\right)(\%)$ was calculated using the measured values for $\kappa_{\mathrm{LF}}$ and $\kappa_{\mathrm{HF}}$ according to the following formula:
$\chi_{\mathrm{fd}}=\left(\kappa_{\mathrm{LF}}-\kappa_{\mathrm{HF}}\right) / \kappa_{\mathrm{LF}} * 100$.

$\chi_{\mathrm{fd}}$ indicates the presence of superparamagnetic crystals smaller than $0.03 \mu \mathrm{m}$, with theoretical values of 14.5-16.9 for magnetite and 11.6-14.3 for maghemite (Dearing 1999).

\subsubsection{Luminescence dating}

Dating was conducted at the luminescence-dating laboratory at the Albert-Ludwigs-University Freiburg.

To determine equivalent doses $\left(D_{\mathrm{e}}\right)$, samples from the lightproof steel tubes were prepared under subdued red light. Wet sieving $(90-200 \mu \mathrm{m})$ was followed by a chemical treatment to remove carbonates and organic matter with $\mathrm{HCl}(20 \%)$ and $\mathrm{H}_{2} \mathrm{O}_{2}(20 \%)$, respectively. Heavy liquid separation (heterosodiumpolytungstate, LST) was used to separate quartz from the remaining mineral matrix at densities between 2.58 and $2.70 \mathrm{~g} / \mathrm{cm}^{3}$. The extracted quartz was subsequently etched with HF (40\%) for 60 min to remove the naturally $\alpha$-irradiated outer rim and potential feldspar contaminations. The etched samples were re-sieved $(90 \mu \mathrm{m})$ to recover the original grain-size fraction. 2-mm aliquots were prepared by mounting grains onto stainless steel cups using silicon oil as adhesive (59 aliquots of CR-2). As the sediment was very poor in sand (especially CR-1), further analysis was performed on the fine-grain fraction of both samples. The polymineral 4-11 $\mu \mathrm{m}$ fraction was separated by Atterberg method after sieving $(90 \mu \mathrm{m})$ and pipetted onto stainless steel cups (12 aliquots, $1.5 \mathrm{mg}$ each). Fine-grain quartz was obtained by treatment of the $4-11 \mu \mathrm{m}$ polymineral fraction with $35 \%$ hexafluorosilicic acid $\left(\mathrm{H}_{2} \mathrm{SiF}_{6}\right)$ for 3 to 6 days. For dose rate determination $\left(\mathrm{D}_{0}\right)$, the contents of primordial radionuclides Uranium $\left({ }^{238} \mathrm{U}\right)$, Thorium $\left({ }^{232} \mathrm{Th}\right)$ and Potassium $\left({ }^{40} \mathrm{~K}\right)$ were detected by gamma spectroscopy using a high-purity germanium detector (Ortec). For polymineral samples, an a-value of $0.08 \pm 0.02$ was used to account for the lower luminescence-efficiency of alpha particles compared to beta and gamma radiation (Rees-Jones 1995). An a-value of $0.03 \pm 0.005$ was assumed for finegrain quartz (Lai et al. 2008). The cosmic dose rate was estimated according to geographical position, altitude and sampling depth.

Equivalent doses were measured on a Lexsyg luminescence reader (Freiberg Instruments) using green diodes and IR laser diodes, respectively. Quartz coarse-grain and quartz fine-grain were measured with a modified OSL SAR-protocol by Murray and Wintle (2000), and for the polymineral fraction, the post-IR-IRSL SAR-protocol by Buylaert et al. (2009) was applied. Immediately after the measurement of the conventional $50^{\circ} \mathrm{C}$ IRSL (infrared stimulated) signal, a second IRSL signal is stimulated at $225^{\circ} \mathrm{C}$. This high-temperature post-IR-IRSL signal is considered to be more stable compared to the conventional $50{ }^{\circ} \mathrm{C}$ IRSL signal. Therefore, the polymineral doses were not corrected for fading. 
Equivalent dose calculation was performed applying the Central Age Model (CAM) and the Minimum Age Model (MAM) according to Galbraith et al. (1999). Luminescence ages were calculated with Adele software (v2017, Degering and Degering 2020).

\subsubsection{Micromorphology}

Thin sections for micromorphological analysis were prepared from oriented and undisturbed soil samples at MKFactory (Stahnsdorf, Germany). Analysis of the thin sections was conducted at the Max-Planck-Institute for Evolutionary Anthropology with a petrographic microscope, at magnifications of $20 \times$ to $200 x$, using oblique incident (OIL), plane- (PPL) and cross-polarized light (XPL). Microscopic description terminology mainly follows Bullock et al. (1985) and Stoops (2003).

\section{Results}

\subsection{Macroscopic description}

The following sequence of sediments is described in stratigraphic order from bottom to top of the profile. All depths are given with respect to the top of unit 2 (see Fig. 5).
Unit 4 represents the base of the profile and consists of consolidated/cemented alluvial fan sediments composed of well-rounded and poorly sorted boulders in a carbonatic matrix (not sampled for further analysis). Unit 3 consists of brown (7.5 YR 4/4), unconsolidated, coarse-grained slope debris (sample 3-2,150-170 cm). The upper 5 to $10 \mathrm{~cm}$ of unit 3 are significantly darker in colour (7.5 YR $3 / 3$ ) and were, therefore, sampled separately (sample 3-1, $130-140 \mathrm{~cm}$ ). There is a gradual transition between units 2 and 3 , indicating post-depositional alteration.

Unit 2 consists of yellowish-brown fine-grained material. The lower part of this unit (sample 2-3, 115-125 cm) has a sandy-silty texture and slightly darker colour (10 YR 4/3). At about $100 \mathrm{~cm}$ below the top of unit 2, the matrix gradually changes into a silty texture free of sand with a slightly lighter colour (10 YR 5/4) (sample 2-2, 70-80 cm; sample $2-1,30-40 \mathrm{~cm}$ ). Within unit 2 , coarse fragments and bedding could not be detected macroscopically.

A prominent disconformity separates unit 2 from the overlying thick deposits of heterogeneous, coarse-grained slope debris designated as unit 1 . Unit 1 is approximately $150 \mathrm{~cm}$ thick and did not show any macroscopic signs of weathering or soil formation.

In the following sections, detailed results for units 2 and 3 are given with respect to grain-size distribution, geochemical and mineralogical composition, microscopic characteristics and luminescence ages.
Fig. 6 Grain-size distribution of the profile Chriso 1. Coloured lines depict single sedigraph fraction distribution between 0.2 and $63 \mu \mathrm{m}$ (right axis). Bars depict portions of 9 discrete grain size classes $(0-2 \mathrm{~mm})$ (left axis). Dashed coloured lines depict cumulative contents of grain size classes ( $0-2 \mathrm{~mm}$ ) (left axis)

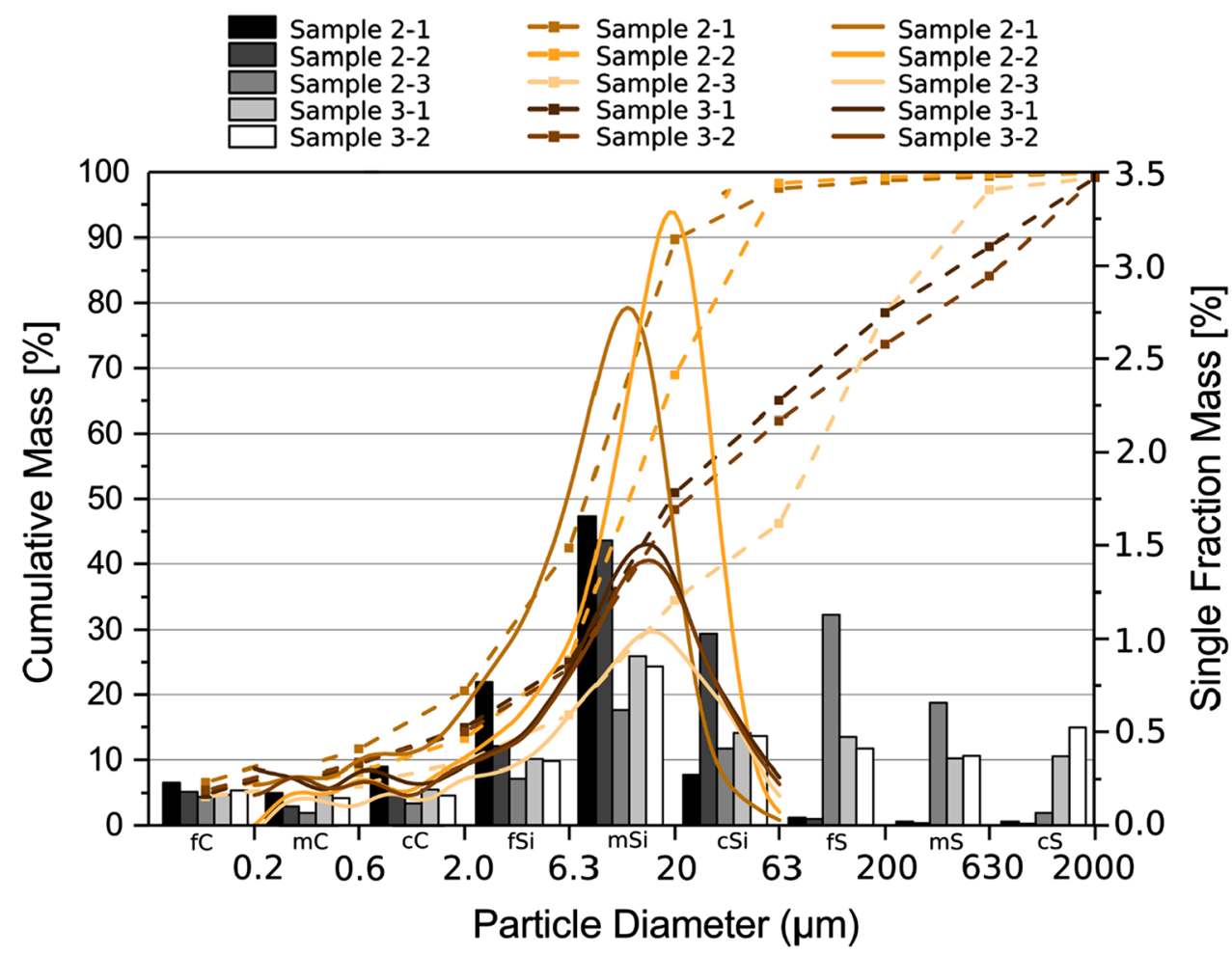




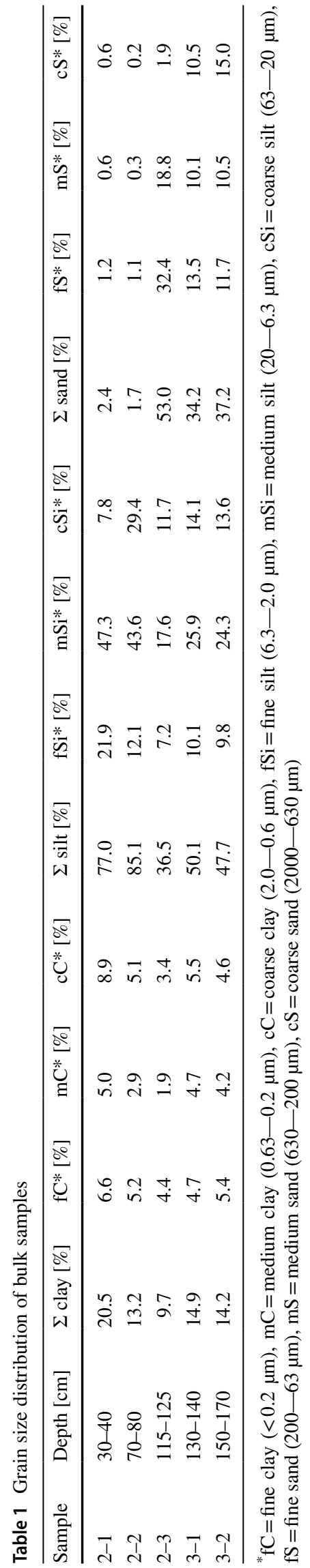

\subsection{Grain-size distribution}

Unit 3 (samples 3-1 and 3-2) has a fairly even grain-size distribution (see Fig. 6 and Table 1). There is a pronounced peak at about $15 \mu \mathrm{m}$ for both samples, which corresponds to the medium silt fraction $(20-6.3 \mu \mathrm{m})$. This fraction comprises about $25 \%$ in both samples.

Sample 2-3 (lower part of unit 2) contains the highest amount of sand of all five samples, mainly in the fine and medium sand fraction. The fine sand fraction $(63-200 \mu \mathrm{m})$ comprises $32 \%$ of the sample, half of which lies between 63 and $125 \mu \mathrm{m}$ (very fine sand-subfraction of the fine sand fraction obtained during sieving procedure, data not separately displayed). Within the clay and silt fractions, there is a peak at $14 \mu \mathrm{m}$ similar to samples from unit 3 .

The upper part of unit 2 (samples 2-1 and 2-2) contains very low quantities of sand (about 2\%). Sample 2-2 contains high amounts of coarse and medium silt, with a very pronounced peak at about $20 \mu \mathrm{m}$. Sample $2-1$ is more finegrained than sample 2-2, with higher contents of coarse clay, fine silt and medium silt, while it is lower in coarse silt than sample $2-2$. There is a highly pronounced peak with a mode at $12 \mu \mathrm{m}$ in sample $2-1$. A minor peak with a mode between 0.6 and $1 \mu \mathrm{m}$ was detected in all five samples.

\subsection{Geochemistry, mineralogy and magnetic susceptibility}

Unit 3 is almost homogeneous in its geochemical composition (Table 2). Both samples (3-1 and 3-2) contain about $19 \% \mathrm{SiO}_{2}, 1.3 \% \mathrm{Fe}_{\mathrm{t}}$ and $2.9 \% \mathrm{Al}_{\mathrm{t}}$. TIC is about $10 \%$ in all three samples. $\mathrm{Fe}_{\mathrm{d}^{-}}$and $\mathrm{Fe}_{\mathrm{o}}$-contents are somewhat higher in sample 3-1, resulting in an increased Fe-weathering index value. The same holds true for both mass-specific magnetic susceptibility $(\chi)$ and frequency-dependent magnetic susceptibility $\left(\chi_{\mathrm{fd}}\right)$. Sample 3-1 also has a considerably higher content of organic carbon than sample 3-2.

Samples from unit 2 are chemically fairly homogeneous. They contain lower amounts of $\mathrm{SiO}_{2}, \mathrm{Fe}_{\mathrm{t}}$ and $\mathrm{Al}_{\mathrm{t}}$ than samples from unit 3 . All three parameters show an increasing trend towards the top of unit 2. TIC is slightly lower than in unit $3 . \mathrm{Fe}_{\mathrm{d}}$-contents as well as the Fe-weathering-indexvalues of sample 2-3 are also lower than in unit 3. In contrast, sample 2-1 has the highest $\mathrm{Fe}_{\mathrm{d}}$-contents, the highest $\mathrm{Fe}_{\mathrm{d}} / \mathrm{Fe}_{\mathrm{t}}$-ratio, and a very high $\mathrm{Fe}$-weathering-index-value. While mass-specific magnetic susceptibility $(\chi)$ is low in unit 2 , frequency-dependent magnetic susceptibility $\left(\chi_{\mathrm{fd}}\right)$ is higher (especially in sample 2-1) than in unit 3. Total contents of sulfur $\left(\mathrm{S}_{\mathrm{t}}\right)$ are very low $(0.03$ to $0.04 \%)$. The Ti/ Al-ratio is nearly constant throughout the profile, as well as TOC-contents, which are also low (0.3-0.4\%).

Mineralogical composition throughout the profile shows only minor variations, with the exception of sample $2-3$ 
Table 2 Geochemical parameters of samples

\begin{tabular}{|c|c|c|c|c|c|c|c|c|c|c|c|c|c|c|}
\hline Sample & $\begin{array}{l}\text { Depth } \\
{[\mathrm{cm}]}\end{array}$ & $\begin{array}{l}\text { pH } \\
\left(\mathrm{CaCl}_{2}\right)\end{array}$ & $\begin{array}{l}\text { TOC } \\
{[\%]}\end{array}$ & TIC [\%] & $\begin{array}{l}\mathrm{SiO}_{2} \\
{[\%]}\end{array}$ & $\begin{array}{l}\mathrm{Al}_{\mathrm{t}} \\
{[\%]}\end{array}$ & $\begin{array}{l}\mathbf{F e}_{\mathrm{t}} \\
{[\%]}\end{array}$ & $\begin{array}{l}\mathbf{S}_{\mathrm{t}} \\
{[\%]}\end{array}$ & $\mathrm{Fe}_{\mathrm{t}} / \mathrm{Al}_{\mathrm{t}}$ & $\begin{array}{l}\mathbf{F e}_{\mathbf{d}} \\
{[\%]}\end{array}$ & $\mathrm{Fe}_{\mathrm{d}} / \mathrm{Fe}_{\mathrm{t}}$ & $\mathbf{T i} / \mathbf{A l}$ & $\mathrm{Fe}_{0}[\%]$ & $\begin{array}{l}\text { Fe-weathering index } \\
{\left[\left(\mathrm{Fe}_{\mathrm{d}}-\mathrm{Fe}_{\mathrm{o}}\right) /\left(\mathrm{Fe}_{\mathrm{t}} / \mathrm{clay}\right)\right]}\end{array}$ \\
\hline $2-1$ & $30-40$ & 7.9 & 0.40 & 9.6 & 14.7 & 2.57 & 1.09 & 0.04 & 0.42 & 0.88 & 0.81 & 0.054 & 0.02 & 16.29 \\
\hline $2-2$ & $70-80$ & 7.8 & 0.36 & 10.3 & 12.4 & 2.02 & 0.84 & 0.04 & 0.42 & n.d.* & n.d.* & 0.051 & n.d.* & n.d.* \\
\hline $2-3$ & $115-125$ & 7.9 & 0.42 & 9.8 & 13.9 & 1.82 & 0.80 & 0.03 & 0.44 & 0.35 & 0.44 & 0.052 & 0.03 & 3.91 \\
\hline $3-1$ & $130-140$ & 7.8 & 0.88 & 8.8 & 19.1 & 2.89 & 1.31 & 0.03 & 0.45 & 0.62 & 0.47 & 0.056 & 0.04 & 6.53 \\
\hline $3-2$ & $150-170$ & 7.8 & 0.46 & 9.0 & 19.4 & 2.91 & 1.26 & 0.03 & 0.43 & 0.52 & 0.41 & 0.057 & 0.02 & 5.57 \\
\hline
\end{tabular}

*n.d.: not determined

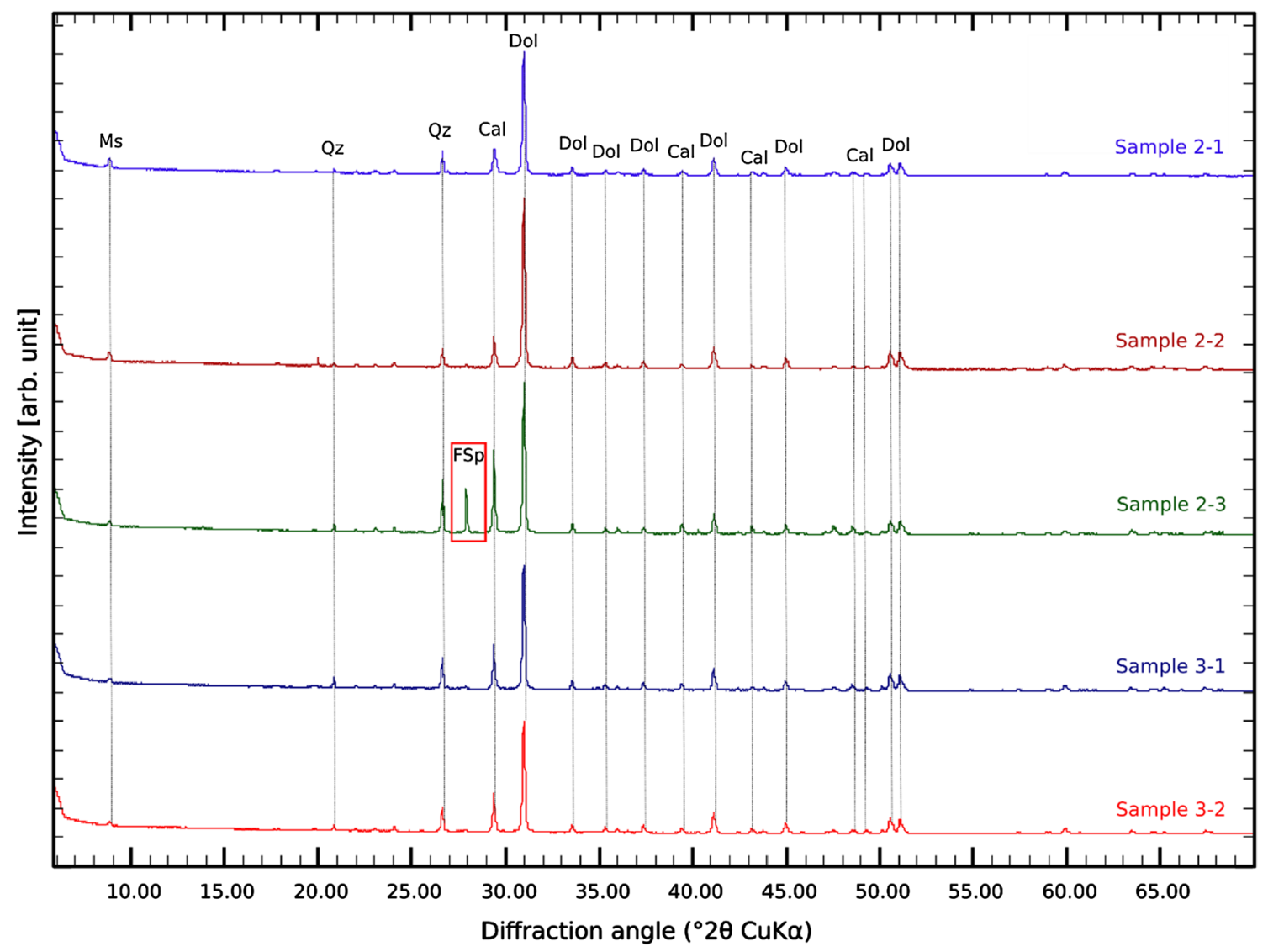

Fig. 7 Diffractograms of all five samples with labelled peaks of main minerals $(\mathrm{Ms}=$ Muscovite, $\mathrm{Qz}=\mathrm{Quartz}, \mathrm{Cal}=\mathrm{Calcite}, \mathrm{Dol}=\mathrm{Dolomite}$, $\mathrm{FSp}=$ Feldspar), Feldspar peak in sample 2-3 highlighted with red rectangle

Table 3 Geophysical and mineralogical parameters of samples

\begin{tabular}{|c|c|c|c|c|c|c|c|c|c|}
\hline \multirow[t]{2}{*}{ Sample } & \multirow[t]{2}{*}{ Depth $[\mathrm{cm}]$} & \multirow[t]{2}{*}{ Munsell colour (moist) } & \multicolumn{5}{|c|}{ Mineralogy $\left(\sum 100 \%\right)$} & \multirow[b]{2}{*}{$\begin{array}{l}\chi\left[10^{-8}\right. \\
\left.\mathrm{m}^{\mathbf{3}} \mathbf{k g}^{-\mathbf{1}}\right]\end{array}$} & \multirow[b]{2}{*}{$\chi_{\mathbf{f d}}[\%]$} \\
\hline & & & Quartz [\%] & Calcite $[\%]$ & Dolomite [\%] & Muscovite [\%] & Feldspar [\%] & & \\
\hline $2-1$ & $30-40$ & $10 \mathrm{YR} 5 / 4$ & 5 & 19 & 63 & 12 & 0 & 0.78 & 11.31 \\
\hline $2-2$ & $70-80$ & $10 \mathrm{YR} 5 / 4$ & 4 & 14 & 74 & 8 & 0 & 0.57 & 9.66 \\
\hline $2-3$ & $115-125$ & $10 \mathrm{YR} 4 / 3$ & 9 & 21 & 53 & 6 & 10 & 0.50 & 9.10 \\
\hline $3-1$ & $130-140$ & $7.5 \mathrm{YR} 3 / 3$ & 9 & 15 & 67 & 9 & 0 & 1.28 & 9.36 \\
\hline $3-2$ & $150-170$ & 7.5 YR 4/4 & 7 & 16 & 68 & 10 & 0 & 0.89 & 8.81 \\
\hline
\end{tabular}


(a)

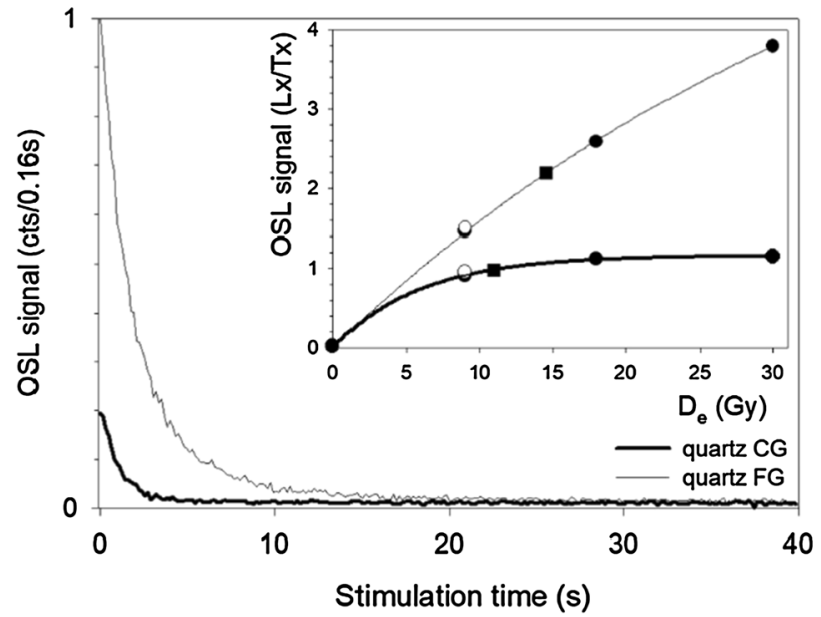

Fig. 8 OSL shine down curves and corresponding dose growth curves (inset) of a coarse-grain quartz aliquot of CR-2 and one finegrain quartz aliquot of the same sample (a). Black squares: natural OSL signal, empty circles: OSL signal of repeated dose at the end of the SAR measurement to check for the quality of the sensitivity

(Fig. 7, Table 3). Both samples from unit 3 consist mainly of dolomite, with minor proportions of calcite, muscovite and quartz. The lower part of unit 2 (sample 2-3) contains considerable amounts of feldspar (10\%). The proportions of dolomite and muscovite in this sample are lower than in all other samples, while the proportions of calcite and quartz are slightly higher. In the middle and upper part of unit 2 (samples 2-1 and 2-2), feldspar was not detected, while contents of quartz, calcite, dolomite and muscovite are similar to those found in samples from unit 3 .

\subsection{Luminescence dating}

Coarse-grain quartz of CR-2 shows poor luminescence properties. The signal intensity is low and saturation is reached at low doses (see Fig. 8a). Furthermore, the dose recovery test failed, and the applied laboratory dose of 15 Gy was underestimated at all chosen preheat temperatures by approximately $20 \%$ (see Fig. 8b).

Fine-grain quartz behaved completely different: the resetting of the OSL signal was slower (despite the absence of feldspar contamination), and the growth curve shows no evidence of saturation (see Fig. 8a and b). Dose recovery tests revealed that known beta doses can be precisely recovered, shown by measured to given dose ratios close to 1 (see Fig. 8b). The ages determined on fine-grained quartz were, therefore, used for interpreting the chronology of the investigated sediment profile. The polymineral fine-grain ages of the IR signal stimulated at $50^{\circ} \mathrm{C}$ underestimate the finegrain quartz ages by about $20 \%$, which can be attributed to the effect of anomalous fading (Huntley and Lamothe 2001). (b)

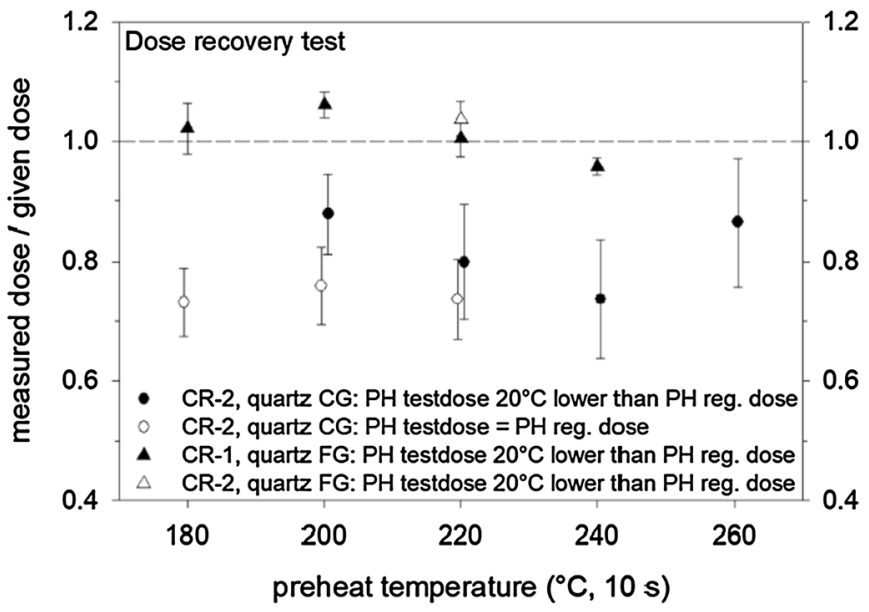

correction. Dose recovery test of coarse-grain quartz sample CR-2 and fine-grain quartz samples CR-1 and CR-2 (b). Three to four aliquots were measured per temperature step $(\mathrm{PH}=$ preheat temperature, $\mathrm{CG}=$ coarse-grain, $\mathrm{FG}=$ fine-grain). A laboratory dose of $15 \mathrm{~Gy}$ was given after bleaching

In contrast, ages derived from the post IR-signal at $25^{\circ} \mathrm{C}$ overestimate the fine-grain quartz ages by 8 to $18 \%$ (see Table 4). This overestimation might be due to residual dose amounts. The determination of the residual dose of sample CR-1 (after bleaching for $500 \mathrm{~s}$ in the Lexsyg solar simulator at $50 \%$ power) resulted in a value of $3.49 \pm 0.41 \mathrm{~Gy}$. Subtracting this value from the measured paleodoses of both samples would result in post-IR-ages identical to the finegrain quartz data within error limits (for luminescence ages presented here, the residual dose was not considered). It is worth noting that the analysis of fine-grain and coarse-grain quartz yielded the same age applying the Central Age Model despite the very different luminescence behaviour. The broad and positively skewed paleodose distribution of the coarsegrained quartz of CR-2 (overdispersion of $26.1 \%$ ) indicates a possibly incomplete resetting of the OSL signal during the last sediment reworking. In this case, the central age model would overestimate the true age. This also applies to the fine-grained samples where averaging effects prevent the detection of individual grain characteristics. However, other reasons like dosimetric inhomogeneities cannot be ruled out. Gamma spectroscopy detected a moderate radioactive disequilibrium in the ${ }^{238} \mathrm{U}$ decay chain of both samples. A partial uranium leaching is indicated by an approximately $25 \%$ lower ${ }^{234} \mathrm{Th}$ activity compared to the ${ }^{214} \mathrm{~Pb}$ and ${ }^{214} \mathrm{Bi}$ activities. The latter were used for dose rate calculation, since their energy peaks are more clearly represented in the gamma ray spectra. An assumed linear uranium leaching would increase the mean OSL ages by only a few hundred years resulting in ages within the error margins of calculated ages (Fig. 9). 


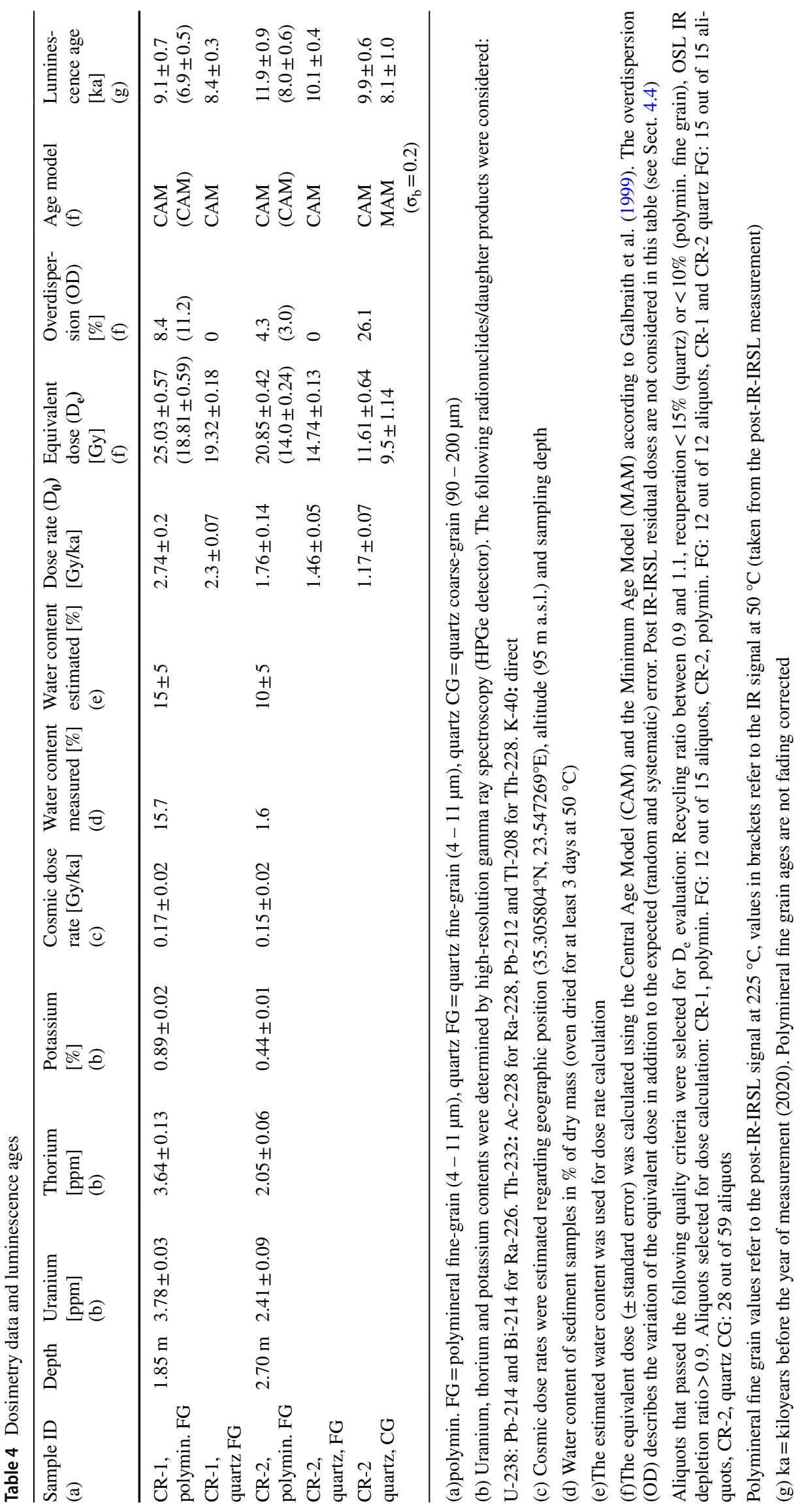


(a)

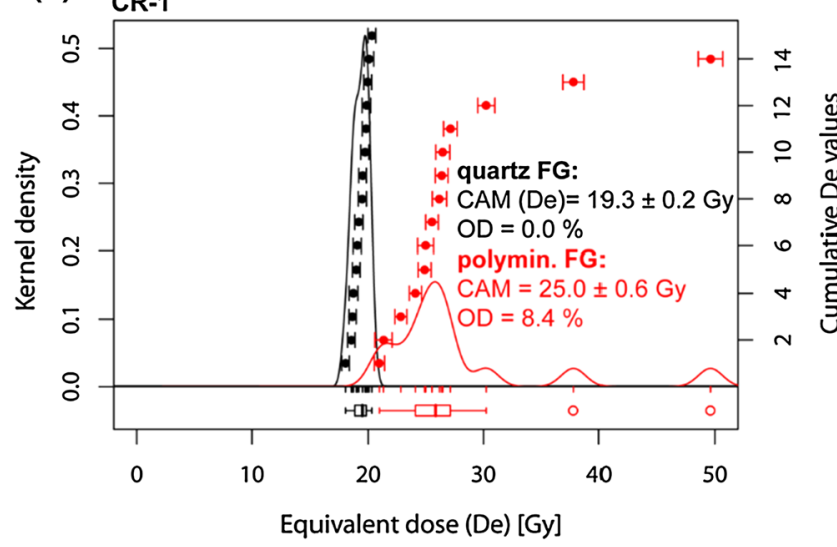

Fig. 9 Individual equivalent doses for all selected aliquots of CR-1 and CR-2 with resulting kernel density estimates. Mean equivalent doses (CAM) and overdispersion values are given. Box plots:

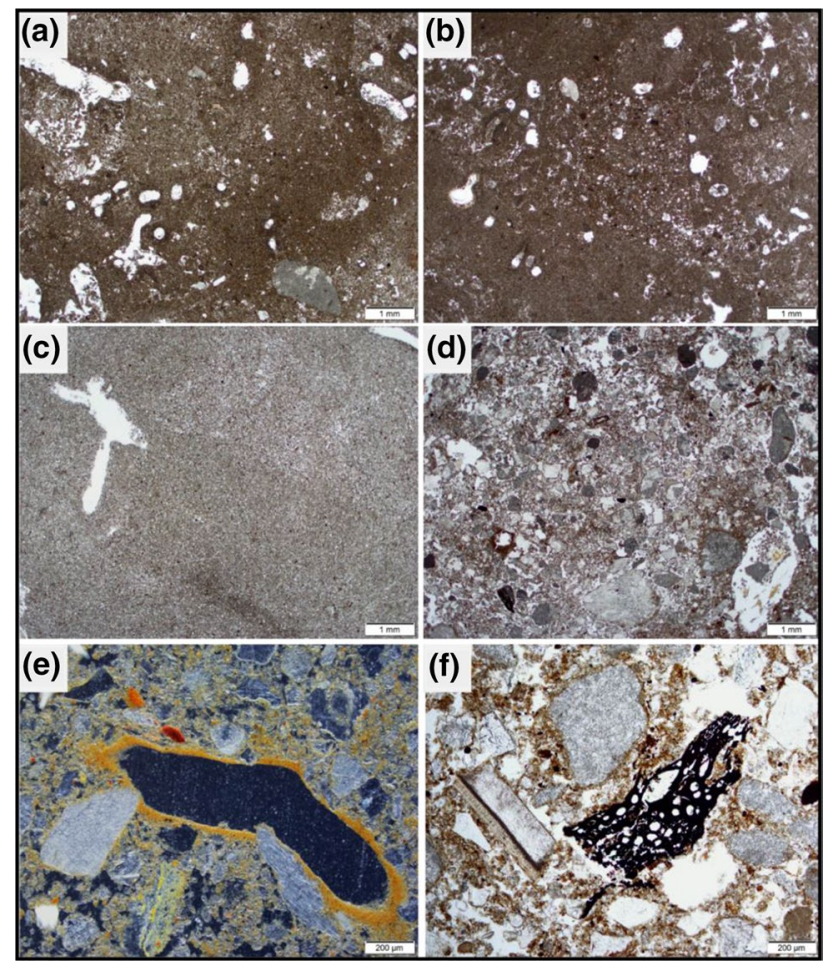

Fig. 10 Microphotographs of thin sections at profile Chriso 1: (a) Mimo 2-1: micritic matrix impregnation and bioturbation (channels), note the micritic hypocoatings of most of the voids (PPL) (b) Mimo 2-1: coarser grained material (sand) in a biogenic infilling (PPL) (c) Mimo 2-2: closely packed silty material with weak micritic impregnation (PPL) (d) Mimo 2-3: coarse material in the lower part of the thin section (PPL) (e) Mimo 2-3: micritic coating of a void with ferruginous mottling (OIL) (f) Mimo 2-3: charcoal (right) and fragment of mollusk shell (left) (PPL)

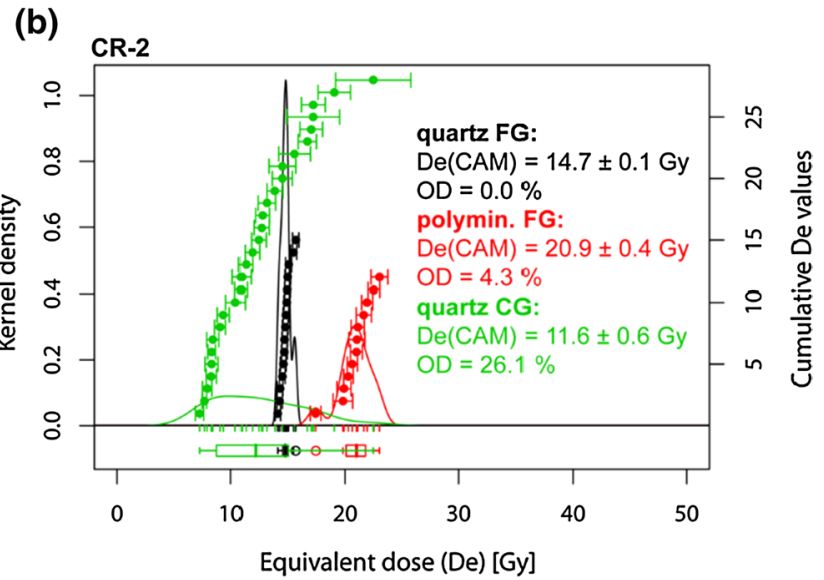

box delimited by the first and third quartile, whiskers defined by the extremes within 1.5 interquartile ranges. Open circles indicate outliers, they were eliminated from CR-1 before applying the CAM

The lower part of the fine-grained sediments (CR-2, corresponding to sample $2-3$ ) was dated to $10 \pm 0.4 \mathrm{ka}(\mathrm{CAM})$, and the upper part of the fine-grained sediments (CR-1, corresponding to sample $2-1$ ) was dated to $8.4 \pm 0.3 \mathrm{ka}$ (CAM) in the fine-grained quartz fraction. These results indicate a sediment deposition during the early Holocene (Preboreal to Boreal).

\subsection{Micromorphology}

In the uppermost thin section (Mimo 2-1), mainly silt-sized material with minor proportions of sand-sized limestone fragments is strongly impregnated by micrit coatings (calcitic crystallitic b-fabric). The apedal and closely packed light greyish-brown material is broken by several channels that often reveal calcitic (micrit) hypocaotings and micritic to sparitic coatings of the void's walls (Fig. 10a). In most cases, passage features as well as biogenic infillings contain material with higher proportions of sand (Fig. 10b) and scattered fragments of mollusk shells.

The material of the second thin section (Mimo 2-2) is lighter in colour than in the upper thin section. It is nearly exclusively silt-sized and less strongly impregnated by micrit coatings (Fig. 10c). Calcitic coatings and hypocoatings of voids are almost completely absent as are mollusk shell fragments and (coarse) sand grains. Evidence of bioturbation, such as channels and passage features, are less abundant.

The lowermost thin section (Mimo 2-3) shows coarsergrained material than the other two thin sections (Fig. 10d). In its upper part it is predominantly fine- to medium sandsized with a weaker micritic impregnation, while the lower part contains even more coarse particles (coarse sand, mollusk shell fragments), but reveals a stronger micritic impregnation. Furthermore, root remains and small pieces 
of charcoal (Fig. 10f) were identified in all parts of the thin section. The intensity of bioturbation is weaker than in the uppermost thin section, but is stronger than in the second sample. Some channels exhibit brown micritic coatings of their walls stained by weak ferruginious mottling (Fig. 10e).

\section{Synthesis and discussion}

\subsection{Profile genesis}

Based on our luminescence dating results, the fine-grained sediments in the upper part of Chriso 1 (unit 2) accumulated during the early Holocene. Unit 3 represents slope debris and contains considerable amounts of sand and coarser particles. As this stratigraphic unit is older than the dated sediments, it was probably deposited during the late Pleistocene. The macroscopic characteristics correspond to most other sediments in the wider study area. However, a pronounced peak with steep flanks at $15 \mu \mathrm{m}$ (Fig. 6) indicates a strong silty component. Consequently, we interpret this input to be of (local) aeolian origin. Whether the input happened pre- or synsedimentary cannot be deduced from the existing data. Stratigraphic unit 3 has most likely been subject to chemical weathering and weak in-situ pedogenesis. The latter is indicated macroscopically by the darker colour, a result of higher contents of organic carbon in sample 3-1, as well as by a small increase in $\mathrm{Fe}_{\mathrm{d}}$, the Fe-weathering-index-value and $\chi$ and $\chi_{\mathrm{fd}}$. Apparently, weathering took place despite the high-carbonate contents. There is no indication of an external input to the uppermost part of unit 3, as samples 3-1 and 3-2 are otherwise almost identical with respect to their geophysical, geochemical and mineralogical composition. This question cannot be resolved based on our data alone.

Unit 2 exhibits very different characteristics compared to the underlying unit. The lower part of unit 2 (sample 2-3) is rich in fine and medium sand and also contains considerable amounts of medium and coarse silt with a mode very similar to the one in unit 3. Furthermore, sample 2-3 contains very small amounts of coarser fragments (coarse sand) and has a considerably different geochemical and mineralogical composition than samples 3-1 and 3-2. Based on these compositional differences, aggradation processes of unit 2 must have been quite different from those of most other slope sediments in the study area, including unit 3 . We, therefore, suggest a local aeolian origin from the coastal plain, nearby beaches and marine shelf that were exposed due to the sealevel-lowstand during the late Pleistocene and early Holocene. In the lowest part of unit 2 (sample 2-3, lower part of thin section Mimo 2-3), the small amount of coarse sand as well as numerous charcoal fragments may be indicators of water transport, although the particles could also have been transported by aeolian processes over short distances. In the middle and upper part of unit 2 (samples 2-2 and 2-1), the sediment is much finer and contains almost no sand-sized particles. The mode shifts from coarse and medium silt in sample $2-2$ to medium and fine silt in sample $2-1$. The peaks of these samples are much more pronounced than in the other three samples, indicating an even better grain-size sorting. Signs of bedding as a result of sheet flow could not be detected macroscopically or through micromorphological analysis. The small amount of coarse sand observed in thin section Mimo 2-1 could well be the result of bioturbation and, therefore, originated from the overlying slope debris, as described in the micromorphological analysis. The geochemical and mineralogical similarity to samples from unit 3 indicates a proximal source area within the same geological unit (Neogene limestones). This is confirmed by the nearly constant Ti/Al-ratio throughout the profile that has been applied successfully for the differentiation of source areas (Sheldon and Tabor 2009). However, the considerable proportions of feldspar in the lower part of unit 2 suggest a distinct source area for parts of the sediments.

Based on our results from several other sites in western and central Crete (data in preparation), we interpret the small peak between 0.6 and $1 \mu \mathrm{m}$, detected in all five samples (Fig. 6), as a representation of a distal dust input from northern Africa. Its deposition would have taken place simultaneously with local aeolian inputs, but due to the relatively short period of deposition, it only represents a minor component.

The geochemical data indicate a considerably higher degree of weathering towards the upper part of unit 2, especially for sample $2-1$, but to a lesser degree also for sample $2-2$ compared to sample $2-3$. This is confirmed by micromorphological findings, especially the redistribution of calcite (hypocoatings and micritic impregnation). However, we could not detect any macroscopic signs of soil formation, and a considerable degree of in-situ chemical weathering seems unlikely due to the abundance of carbonates, although it apparently took place to some degree in the upper part of stratigraphic unit 3 . We, therefore, assume that the profile was truncated before the aggradation of unit 1 and that the original upper parts of unit 2 are missing. The higher amounts of $\mathrm{Al}_{\mathrm{t}}, \mathrm{Fe}_{\mathrm{t}}, \mathrm{Fe}_{\mathrm{d}}$ and the corresponding $\mathrm{Fe}$-weathering-index-value, as well as the higher values for $\chi$ and $\chi_{\mathrm{fd}}$ in the upper part of unit 2 may be the result of a pre-depositional weathering of the substrate. They could also be attributed to post-depositional inputs (e.g. of Saharan dust or through bioturbation from overlying sediments), a matter that cannot be resolved based on the data collected so far alone.

\subsection{Origin of sediments}

As a possible source area of the aeolian sediments, we propose the nearby coastal plain, especially the shoreline and 
(exposed) continental shelf. Based on bathymetric data (see Fig. 2), several hundred metres of current seafloor would have been exposed with the relative sea level being 60 to $100 \mathrm{~m}$ lower than today during the late Pleistocene around $12 \mathrm{ka} \mathrm{BP}$ in southwestern Crete (Lambeck and Purcell 2005; Mouslopolou et al. 2017). Despite a rising sea level during the early Holocene, it was still considerably lower than today during the time of deposition of the studied aeolian sediments (Lambeck and Purcell 2005). In the shallower Stomio Bay, a few kilometres north of the profile, the exposure of seafloor may have extended up to $2000 \mathrm{~m}$ seawards compared to the current shoreline. In its lower reaches, Stomio River passes through an extensive area composed of Upper Triassic limestones and dolomites that could have been the source-area of the fluvial and/or marine sediments that were later redeposited in the sampled profile. Furthermore, the coastal plain is made up of Neogene (marly) limestones with silt and sand intercalations (see Fig. 2). It seems probable that these formations act as a proximal source area for the sampled sediments.

As total contents of sulphur are very low in all samples (see Tables 2, 3), sulphates such as $\mathrm{CaSO}_{4}$ apparently do not play a major role in substrate composition. They were also not detected in mineralogical analysis. A source area within the extensive outcrops of evaporites (anhydrite/ gypsum) in the area around the profile can, therefore, be ruled out. Furthermore, the drainage area of Stomio River is comprised of carbonate-free metamorphic rocks belonging to the Phyllite-Quartzite-Unit and, therefore, cannot be the main source area of the aeolian sediment. However, reliable data, incorporating the physical and chemical characteristics of basement rocks in the potential source areas, need to be generated as part of future investigations.

Silty sediments with characteristics similar to those of samples $2-1$ and 2-2 were identified within a polje-like depression within the coastal plain about $1 \mathrm{~km}$ south-west of the sampled profile. However, due to intense agricultural land-use activity and limited access, the lateral extent of these sediments could not be determined. Based on preliminary results of geochemical parameters and grain-size distribution, these sediments resemble sediments comprising unit 2 in the Chriso 1 profile and will be analyzed during our ongoing investigation.

Within the marly geological formations of Crete, fluvially redeposited silty sediments are very common. The latter have previously been mistaken for loess-like aeolian sediments (Nihlén 1990; Pye 1992). However, grain-size characteristics of such silty alluvium are distinct from those discussed here.

Sediments of unit 2 have been preserved mainly as a result of the deposition of younger slope sediments (unit 1). Due to the lack of data for unit 1 (including depositional ages), we can only assume that the duration of exposure of unit 2 was rather short, as silty sediments are especially prone to erosion. So far, aeolian sediments with similar characteristics have not been detected or described for other locations in western Crete. A similar sandy-silty deposit on top of late Pleistocene alluvial fan sediments has been described by Mousloupolou et al. (2017) for the southern coast of Western Crete. It was dated to approximately $25 \mathrm{ka}$ BP. Furthermore, sandy aeolian sediments deposited during the early Holocene have been found by Mandel and Simmons (1997) in a rock shelter in southern Cyprus. For Crete, we would expect such accumulations to be covered by younger reddish-brown slope deposits as represented by unit 1 and, therefore, be largely undetectable.

\subsection{Landscape evolution and paleoenvironmental conditions}

In summary, we propose the following chronology of profile genesis at Chriso 1. During the late Pleistocene with considerable parts of the marine shelf exposed, coarse-grained slope debris including aeolian sediments were deposited in a sediment trap (on a fault scarp), probably a small valley or gully head. During a short phase of landscape stability (probably an interstadial period), these sediments experienced some degree of weathering and soil formation, corresponding to "Late Glacial Soils" described for Koroni (Southern Peloponnese, Greece) by Paepe et al. (1990) and attributed to the Lascaux, Bølling and Allerød Interstadiales (Greek terminology: Philippi and Xanthi). Similar findings were described by Thiem (1981) for north-western Greece and by Brunnacker (1979) for Crete and the coastal plain of Israel.

During the early Holocene, an exceptionally dry period and concomitant sparse vegetative cover caused aeolian sedimentation in the study area. Accumulation of windblown sand and silt was followed by aggradation of loesslike sediment. The shift from sandy to silty aeolian sediment could be the result of sea level fluctuations that have been described by Siddall et al. (2003) and Mouslopolou et al. (2017) for the late Pleistocene and early Holocene. A rising sea level during the early Holocene may have flooded the source areas of sandy material comprising the lower part of unit 2 (sample 2-3). Also, minor shifts in paleoclimatic and -ecological conditions such as humidity, wind speed, or soil cover could have easily altered the patterns of aeolian transport and caused the grain-size shift (Vandenberghe et al. 2018). Furthermore, it is possible that two local source areas contributed simultaneously to the deposit: sandy material from the exposed continental shelf and silty surface material from the Neogene marly limestones of the coastal plain, as proposed in a different geomorphological setting by Wolf et al. (2019) for phases of high aridity. Also, two distinct source areas would account for the differences in 
luminescence properties of the fine-grain and coarse-grain quartz in sample CR-2 as well as the contents of feldspar detected by mineralogical analysis in the sandy part of unit 2.

Though strongly dependent on the definition applied (Iriondo and Kröhling 2007; Sprafke and Obreht 2016; Vandenberghe et al. 2018), we propose to classify the described sediments as loess or loess-like based on the proposed aeolian transport mechanism, the predominantly silty grainsizes, the deposition under comparatively cold and arid conditions and the abundance of carbonates. Furthermore, the micromorphologically-detected micritic matrix impregnation resulting in a calcitic crystallitic b-fabric appears to have a stabilizing effect on the macroscopic structure of the sampled sediments, something very similar to a process labelled loessification, which was proposed by Sprafke and Obreht (2016) as a main criterion for loess.

After an unknown period of landscape stability with initial weathering and soil formation, the deposit was probably truncated and subsequently sealed and preserved by the deposition of slope sediments. The latter could be the result of a pre-anthropogenic landscape process described for the early Holocene in the eastern Mediterranean (Dusar et al. 2011). Based on the results of their palynological research, Bottema and Sarpaki (2003) concluded that the lowlands of Crete were drier during the first three millennia of the Holocene compared to the modern climate. According to their findings, the driest phase was around $8000 \mathrm{BP}$, which corresponds to the upper part of the profile analysed here, while a significant climatic change with increased precipitation facilitating the spread of oak forests only started around 7.5 ka BP (Bottema and Sarpaki 2003). Similarly, Heymann et al. (2013) deduced an increase in summer aridity between 10.5 and $8.7 \mathrm{ka} \mathrm{BP}$ based on geochemical data for lake sediments on the Peloponnese (Greece). Also, pronounced aridity during summer and an increase in fire intensity during the early Holocene was suggested by Peyron et al. (2011) based on a pollen sequence from Lake Tenaghi Philippon (Greece). Contrary to these findings, according to Robinson et al. (2006) and Roberts et al. (2011), the first millennia of the early Holocene were the wettest phase of the last $25 \mathrm{ka}$ throughout the Levante and the eastern Mediterranean, with a single short cooling event at $8.2 \mathrm{ka} \mathrm{BP}$ (correlated with Bond event 5). While this event may correspond to the upper part of unit 2 within the studied profile, the general regional climatic trend during the early Holocene does not appear to favour aeolian transport processes. Cold and dry periods within the south-eastern Aegean Sea were identified by Triantaphyllou et al. (2009) based on a multi-proxy study of marine cores for the period between 11.5 and $9.3 \mathrm{ka} \mathrm{BP}$ as well as the mentioned Misox Oscillation at $8.2 \mathrm{ka} \mathrm{BP}$. In a sedimentological study by Theodorakopoulou et al. (2012), the highest fluvial sedimentation rates in north-eastern Crete were correlated with the warm and wet period between 7.6 and $6.4 \mathrm{ka} \mathrm{BP}$. Unit 1 in our profile probably corresponds to this phase of increased precipitation and natural slope processes but may also be the result of later processes caused by anthropogenic land use. Against this background, questions regarding the variation of local climatic conditions during the early Holocene in (western) Crete with respect to regional climatic trends remain to be investigated.

\section{Conclusion and future research}

Our findings indicate that under dry climatic conditions with low vegetation cover during the early Holocene, aeolian sediments were mobilized and deposited in western Crete on a local to regional scale. However, so far no similar deposits have been identified, probably due to the poor conditions for preservation or as a result of burial by younger coarsegrained sediments during the Holocene. Hence, our findings represent the first dated sequence of early Holocene aeolian sediments for Crete. Questions regarding the distribution pattern of these sediments, their source area(s) and their composition still remain unanswered. More data are needed to accurately assess the age of the overlying and underlying slope sediments and the fossil soil (sample 3-1).

Future investigations should include the sampling of potential source areas, a more extended and detailed sampling and analysis of the profile itself (including units 1 and 4 as well as numerical dating for units 1 and 3), as well as extensive fieldwork in order to identify similar sediments in south-western Crete. Further findings regarding the late Pleistocene to early Holocene paleoclimatic conditions and landscape evolution would be very valuable to establish a connection between more arid zones in northern Africa and the temperate regions of Greece, the Adriatic Sea, and continental Europe.

Supplementary Information The online version contains supplementary material available at https://doi.org/10.1007/s42990-021-00061-w.

Acknowledgements We thank Daniel Grigor (Institute for Geography, Leipzig University) for assistance in field work. We thank Doris Bergmann-Doerr and Dagmar Schneider (Laboratory of Institute of Physical Geography at Goethe-University Frankfurt am Main) for $\mathrm{Fe}_{\mathrm{o}} /$ $\mathrm{Fe}_{\mathrm{d}}$-extraction and measurement. We are grateful to Moritz Liesegang (AB Minerology-Petrology, Institute of Geological Sciences, FU Berlin) for help with XRD-measurements and interpretation of results. We also thank the Institute of Geology and Mineral Exploration of Greece (IGME) for the fieldwork permit. We are grateful to Nadav Nir (AB Physical Geography, Institute of Geographical Sciences, FU Berlin) for helpful comments and suggestions on the manuscript. We would also like to thank two anonymous reviewers for the helpful comments on the manuscript.

Author contributions FK, SH and JH carried out sampling/field work. FK and JH cooperated in the analysis of data, interpretation of results 
and manuscript preparation. $\mathrm{SH}$ provided thin section analysis and interpretation of results. AF performed luminescence dating and interpretation of results. BS performed analysis of grain sizes and element contents.

Funding Open Access funding enabled and organized by Projekt DEAL. Funding for OSL-measurements as well as parts of geochemical and geophysical analysis were provided by the Department of Research Services of Leipzig University.

Data availability Raw grain size data relating to this paper can be found in the Supplement.

Code availability Not applicable.

\section{Declarations}

Conflicts of interest The authors declare that they have no conflicts of interest.

Open Access This article is licensed under a Creative Commons Attribution 4.0 International License, which permits use, sharing, adaptation, distribution and reproduction in any medium or format, as long as you give appropriate credit to the original author(s) and the source, provide a link to the Creative Commons licence, and indicate if changes were made. The images or other third party material in this article are included in the article's Creative Commons licence, unless indicated otherwise in a credit line to the material. If material is not included in the article's Creative Commons licence and your intended use is not permitted by statutory regulation or exceeds the permitted use, you will need to obtain permission directly from the copyright holder. To view a copy of this licence, visit http://creativecommons.org/licenses/by/4.0/.

\section{References}

Boix C, Calvo A, Imeson AC, Schoorl JM, Soto S, Tiemessen IR (1995) Properties and erosional response of soils in a degraded ecosystem in Crete (Greece). Environ Monit Assess 37:79-92. https://doi.org/10.1007/BF00546881

Bottema S (1980) Palynological investigations on Crete. Rev Palaeobot Palynol 31:193-217. https://doi.org/10.1016/0034-6667(80) 90027-5

Bottema S, Sarpaki A (2003) Environmental change in Crete: a 9000year record of Holocene vegetation history and the effect of the Santorini eruption. Holocene 13:733-749. https://doi.org/10.1191/ 0959683603hl659rp

Brunnacker K (1979) Zur Bodengeschichte des Jungquartärs im Mediterranen Raum. Zeitschrift für Geomorphologie, Suppl.-Bd 33:109-117

Brunović D, Miko S, Hasan O, Papatheodorou G, Ilijanić N, Miserocchi S, Correggiari A, Geraga M (2020) Late Pleistocene and Holocene paleoenvironmental reconstruction of a drowned karst isolation basin (Lošinj Channel, NE Adriatic Sea). Palaeogeogr Palaeoclimatol Palaeoecol 544:109587. https://doi.org/10.1016/j. palaeo.2020.109587

Bullock P, Fedoroff N, Jongerius A (1985) Handbook for soil thin section description. Waine Research Publications, Albrighton

Butzer KW (2005) Environmental history in the Mediterranean world: cross-disciplinary investigation of cause-and-effect for degradation and soil erosion. J Archaeol Sci 32:1773-1800. https://doi. org/10.1016/j.jas.2005.06.001
Buylaert JP, Murray AS, Thomsen KJ, Jain M (2009) Testing the potential of an elevated temperature IRSL signal from K-feldspar. Radiat Meas 44:560-565. https://doi.org/10.1016/j.radmeas.2009. 02.007

Christidis GE, Perdikatsis V, Apostolaki C (2010) Mineralogy of the Saharan aeolian dust in Crete: examples from the period 2004 2009. Geosociety 43:2570-2576. https://doi.org/10.12681/bgsg. 11664

Dearing J (1999) Environmental magnetic susceptibility: using the Bartington MS2 System. Bartington instruments, Oxford

Degering D, Degering A (2020) Change is the only constant-timedependent dose rates in luminescence dating. Quat Geochronol 58:1-14. https://doi.org/10.1016/j.quageo.2020.101074

DIN EN 15936:2020-08-Entwurf (2020) Schlamm, behandelter Bioabfall, Boden und Abfall-Bestimmung des gesamten organischen Kohlenstoffs (TOC) mittels trockener Verbrennung; Deutsche Fassung

DIN ISO 10390 (2000) Bodenbeschaffenheit—Bestimmung des pH Berlin

DIN ISO 18129 (2011) Baugrund, Untersuchung von Bodenproben - Kalkgehaltsbestimmung.

DIN ISO19684-1 (1977) Bodenuntersuchungsverfahren im Landwirtschaftlichen Wasserbau; Chemische Laboruntersuchungen Bestimmung des pH-Wertes des Bodens und Ermittlung des Kalkbedarfs Berlin

Doebelin N, Kleeberg R (2015) Profex: a graphical user interface for the Rietveld refinement program BGMN. J Appl Crystallogr 48:1573-1580. https://doi.org/10.1107/S1600576715014685

Durn G (2003) Terra Rossa in the Mediterranean region: parent materials, composition and origin. Geologica Croatia 56:83-100

Dusar B, Verstraeten G, Notebaert B, Bakker J (2011) Holocene environmental change and its impact on sediment dynamics in the Eastern Mediterranean. Earth Sci Rev 108:137-157. https://doi. org/10.1016/j.earscirev.2011.06.006

Earth Resources Observation And Science (EROS) Center (2017) Declassified Satellite Imagery - 3

Egli BR (1993) Ökologie der Dolinen im Gebirge Kretas (Griechenland). Dissertation, Universität Zürich

Fassoulas CG (2001) Field guide to the geology of Crete

Galbraith RF, Roberts RG, Laslett GM, Yoshida H, Olley JM (1999) Optical dating of single and multiple grains of quartz from jinmium rock shelter, norther Australia: Part I, experimental design and statistical models. Archaeometry 41:339-364. https://doi.org/ 10.1111/j.1475-4754.1999.tb00987.x

Gen. St. d. H. Abt. f. Kr. Kart. und Verm. Wes. (1941) Deutsche Heereskarte: Griechenland 1:50 000 (Insel Kreta). Blatt Nr. 4 Kastelli, 1st edn., Berlin

Geraga M, Ioakim C, Lykousis V, Tsaila-Monopolis S, Mylona G (2010) The high-resolution palaeoclimatic and palaeoceanographic history of the last 24,000years in the central Aegean Sea, Greece. Palaeogeogr Palaeoclimatol Palaeoecol 287:101-115. https://doi.org/10.1016/j.palaeo.2010.01.023

Geraga M, St. Tsaila-Monopolis, Ioakim C, Papatheodorou G, Ferentinos G, (2000) Evaluation of palaeoenvironmental changes during the last 18,000 years in the Myrtoon basin, SW Aegean Sea. Palaeogeogr Palaeoclimatol Palaeoecol 156:1-17. https:// doi.org/10.1016/S0031-0182(99)00123-6

Ghilardi M, Psomiadis D, Andrieu-Ponel V, Colleu M, Sotiropoulos P, Longo F, Rossi A, Amato V, Gasse F, Sinibaldi L, Renard M, Bicket A, Delanghe D, Demory F, Fleury J (2018) First evidence of a lake at Ancient Phaistos (Messara Plain, South-Central Crete, Greece): Reconstructing paleoenvironments and differentiating the roles of human land-use and paleoclimate from Minoan to Roman times. The Holocene 2:095968361877147. https://doi.org/10.1177/0959683618771473 
Ghilardi M, Revelles J, Glais A, Theodorakopoulou K, Theodoropoulou T, Lespez L, Longo F, Rossi A, Bellier O, Benedetti L, Fleury J (2019) Reconstructing human-environment interactions in the western Messara Plain (Phaistos, Crete, Greece) from the emergence of city states to Byzantine times. J Archaeol Sci Rep 26:101909. https://doi.org/10.1016/j.jasrep.2019.101909

Goldberg P, Macphail RI (2003) Short contribution: Strategies and techniques in collecting micromorphology samples. Geoarchaeology 18:571-578. https://doi.org/10.1002/gea.10079

Gvirtzman G, Wieder M (2001) Climate of the last 53,000 Years in the eastern Mediterranean, based on soil-sequence Stratigraphy in the coastal plain of Israel. Quatern Sci Rev 20:1827-1849. https://doi.org/10.1016/S0277-3791(01)00008-7

Hellenic National Meteorological Service (2020) Climatic Atlas of Greece. http://climatlas.hnms.gr/sdi/?lang=EN

Hempel L (1982) Jungquartäre Formungsprozesse in Südgriechenland und auf Kreta. Nordrhein-Westfalen: Forschungsberichte des Landes Nordrhein-Westfalen, 3114 : Fachgruppe Physik, Chemie, Biologie. Westdt. Verl., Opladen

Hempel L (1984) Beobachtungen und Betrachtungen zur jungquartären Reliefgestaltung der Insel Kreta. In: Hempel L (ed) Geographische Beiträge zur Landeskunde Griechenlands. Ferdinand Schöningh, Paderborn, pp 9-40

Hempel L (1987) Beobachtungen und Aspekte zur klimamorphologischen Stellung von Schutt und Schottern in den Hochgebirgen der Insel Kreta. Geoökodynamik 8:49-78

Hempel L (1991) Forschungen zur physischen Geographie der Insel Kreta im Quartär: Ein Beitrag zur Geoökologie des Mittelmeerraumes. Abhandlungen der Akademie der Wissenschaften in Göttingen. Mathematisch-Physikalische Klasse, F. 3, 42. Vandenhoeck \& Ruprecht, Göttingen

Heymann C, Nelle O, Dörfler W, Zagana H, Nowaczyk N, Xue J, Unkel I (2013) Late Glacial to mid-Holocene palaeoclimate development of Southern Greece inferred from the sediment sequence of Lake Stymphalia (NE-Peloponnese). Quatern Int 302:42-60. https://doi.org/10.1016/j.quaint.2013.02.014

Institute of Geology and Mineral Exploration (2002) Geological Map of Greece 1:50 000: Palaeohora Sheet

Iriondo MH, Kröhling DM (2007) Non-classical types of loess. Sed Geol 202:352-368. https://doi.org/10.1016/j.sedgeo.2007.03. 012

Jouffroy-Bapicot I, Vannière B, Iglesias V, Debret M, Delarras J-F (2016) 2000 Years of Grazing History and the Making of the Cretan Mountain Landscape. Greece Plos ONE 11:e0156875. https:// doi.org/10.1371/journal.pone.0156875

Kelletat D (1979) Geomorphologische Studien an den Küsten Kretas: Beiträge zur regionalen Küstenmorphologie des Mittelmeerraumes. Abhandlungen der Akademie der Wissenschaften in Göttingen. Mathematisch-physikalische Klasse. Folge 3, Nr. 32. Vandenhoeck \& Ruprecht, Göttingen

Kelletat D (1996) Perspectives in Coastal Geomorphology of Western Crete, Greece (with 13 figures). In: Kelletat D, Psuty NP (eds) Field methods and models to quantify rapid coastal changes: Proceedings of the Field Symposium, Crete, Greece, April 1994. Borntraeger, Berlin, pp 1-19

Lai ZP, Zöller L, Fuchs M, Brückner H (2008) Alpha efficiency determination for OSL of quartz extracted from Chinese loess. Radiat Meas 43:767-770. https://doi.org/10.1016/j.radmeas.2008.01.022

Lambeck K, Purcell A (2005) Sea-level change in the Mediterranean Sea since the LGM: model predictions for tectonically stable areas. Quatern Sci Rev 24:1969-1988. https://doi.org/10.1016/j. quascirev.2004.06.025

Lespez L, Dalongeville R, Pastre J-F, Darmon F, Mathieu R, Poursoulis G (2003) Late-Middle-Holocene palaeo-environmental evolution and coastline changes of Malia (Crete). In: Fouache E (ed) The
Mediterranean World Environment and History (Collection Environment). Elsevier, Paris, pp 439-452

Lucke B, Schmidt U (2015) Grain size analysis of calcareous soils and sediments: intermethod comparison with and without calcium carbonate removal. In: Lucke B, Bäumler R, Schmidt M (eds) Soils and sediments as archives of landscape change: Geoarchaeology and landscape change in the subtropics and tropics. Selbstverlag der Fränkischen Geographischen Gesellschaft in Kommission bei Palm \& Enke, Erlangen, pp 83-98

Lydakis-Simantiris N, Pentari D, Perdikatsis V, Manoutsoglou E, Moraetis D, Apostolaki C (2005) Mineralogical, geochemical and nutrient analysis of soils from Omalos polje -plateau, Western Crete. In: pp 207-211

Mandel RD, Simmons AH (1997) Geoarchaeology of the Akrotiri Aetokremnos rockshelter, Southern Cyprus. Geoarchaeology 12:567-605. https://doi.org/10.1002/(SICI)1520-6548(199709) 12:6\%3c567:AID-GEA4\%3e3.0.CO;2-X

Martha SO, Dörr W, Gerdes A, Krahl J, Linckens J, Zulauf G (2017) The tectonometamorphic and magmatic evolution of the Uppermost Unit in central Crete (Melambes area): constraints on a Late Cretaceous magmatic arc in the Internal Hellenides (Greece). Gondwana Res 48:50-71. https://doi.org/10.1016/j.gr.2017.04. 004

Mehra OP, Jackson ML (1960) Iron oxide removal from soils and clays by a dithionite-citrate system buffered with sodium bicarbonate. In: Swineford A (ed) Clays and Clay Minerals: Proceedings of the Seventh National Conference on Clays and Clay Minerals. Elsevier Science, Burlington, pp 317-327

Moraetis D, Perdikatsis V, Pentari D, Manoutsoglou E, Apostolaki C, Lydakis-Simantiris N (2006) A study on the correlation of the properties of parent rock and soils of different geological origin. In: Advances in Mineral Resources Management and Environmental Geotechnology, pp 349-354

Moraetis D, Paranychianakis NV, Nikolaidis NP, Banwart SA, Rousseva S, Kercheva M, Nenov M, Shishkov T, de Ruiter P, Bloem J, Blum WEH, Lair GJ, van Gaans P, Verheul M (2015) Sediment provenance, soil development, and carbon content in fluvial and manmade terraces at Koiliaris River Critical Zone Observatory. J Soils Sediments 15:347-364. https://doi.org/10.1007/ s11368-014-1030-1

Morris MW (2002) Soil science and archaeology: Three test cases from Minoan Crete. Prehistory monographs, vol 4. Institute for Aegean Prehistory; Oxbow, Philadelphia, Penn., Oxford

Mourtzas N, Kolaiti E, Anzidei M (2016) Vertical land movements and sea level changes along the coast of Crete (Greece) since Late Holocene. Quatern Int 401:43-70. https://doi.org/10.1016/j. quaint.2015.08.008

Mouslopoulou V, Begg J, Fülling A, Moraetis D, Partsinevelos P, Oncken O (2017) Distinct phases of eustatic and tectonic forcing for late Quaternary landscape evolution in southwest Crete. Greece Earth Surf Dynam 5:511-527. https://doi.org/10.5194/ esurf-5-511-2017

Nemec W, Postma G (1993) Quaternary alluvial fans in southwestern Crete: sedimentation processes and geomorphic evolution. In: Marzo M, Puigdefabregas C (eds) Alluvial Sedimentation: Special Publication 17 of the IAS. Wiley, Oxford, pp 235-276

Nevros K, Zvorykin I (1939) Zur Kenntnis der Böden der Insel Kreta (Griechenland). Bodenkundliche Forschungen VI:242-307

Nihlén T (1990) Eolian processes in southern Scandinavia and the Mediterranean area. Meddelanden $\mathrm{fr}^{\circ}$ an Lunds Universitets. Geografiska Institutioner. Avhandlingar, vol 110. Univ. Press, Lund

Nihlén T, Mattsson JO (1989) Studies on Eolian Dust in Greece. Geografiska Annaler. Series A, Physical Geography 71:269. https:// doi.org/10.2307/521398 
Nihlén T, Olsson S (1995) Influence of eolian dust on soil formation in the Aegean area. Zeitschrift für Geomorphologie, N.F. 39:341-361

Nihlén T, Solyom Z (1986) Dust storms and eolian deposits in the Mediterranean area. Geologiska Föreningen i Stockholm Förhandlingar 108:235-242. https://doi.org/10.1080/11035898609454688

Nihlén T, Solyom Z (1989) Possible influence of Saharan dust on soils in Crete. Geologiska Föreningen i Stockholm Förhandlingar 111:25-33. https://doi.org/10.1080/11035898909454756

Paepe R, Mariolakos I, van Overloop E, Keppens E (1990) Last Interglacial-Glacial north-south Geosoil Traverse (from stratotypes in the North Sea Basin and in the eastern Mediterranean). Quatern Int 5:57-70. https://doi.org/10.1016/1040-6182(90)90025-Y

Pope R, Wilkinson K, Skourtsos E, Triantaphyllou M, Ferrier G (2008) Clarifying stages of alluvial fan evolution along the Sfakian piedmont, southern Crete: New evidence from analysis of post-incisive soils and OSL dating. Geomorphology 94:206-225. https://doi. org/10.1016/j.geomorph.2007.05.007

Pope RJ, Candy I, Skourtsos E (2016) A chronology of alluvial fan response to Late Quaternary sea level and climate change. Crete Quat Res 86:170-183. https://doi.org/10.1016/j.yqres.2016.06. 003

Poser H (1957) Klimamorphologische Probleme auf Kreta. Z Geomorphol 1:113-142

Pye K (1992) Aeolian dust transport and deposition over crete and adjacent parts of the mediterranean sea. Earth Surf Process Landforms 17:271-288. https://doi.org/10.1002/esp.3290170306

Rackham O, Moody JA (1996) The making of the Cretan landscape, 5th edn. Manchester University Press, Manchester [u.a.]

Rapp A, Nihlén T (1986) Dust storms and eolian deposits in North Africa and the Mediterranean. Geoökodynamik:41-62

Rees-Jones J (1995) Optical dating of young sediments using FineGrain quartz. Ancient TL:9-14

Roberts N, Eastwood WJ, Kuzucuoğlu C, Fiorentino G, Caracuta V (2011) Climatic, vegetation and cultural change in the eastern Mediterranean during the mid-Holocene environmental transition. The Holocene 21:147-162. https://doi.org/10.1177/09596 83610386819

Robinson SA, Black S, Sellwood BW, Valdes PJ (2006) A review of palaeoclimates and palaeoenvironments in the Levant and Eastern Mediterranean from 25,000 to 5000 years BP: setting the environmental background for the evolution of human civilisation. Quatern Sci Rev 25:1517-1541. https://doi.org/10.1016/j.quasc irev.2006.02.006

Rossignol-Strick M, Planchais N, Paterne M, Duzer D (1992) Vegetation dynamics and climate during the deglaciation in the south Adriatic basin from a marine record. Quatern Sci Rev 11:415423. https://doi.org/10.1016/0277-3791(92)90023-2

Scheffers A, Scheffers S (2007) Tsunami deposits on the coastline of west Crete (Greece). Earth Planet Sci Lett 259:613-624. https:// doi.org/10.1016/j.eps1.2007.05.041

C Siart (2010) Geomorphologisch-geoarchäologische Untersuchungen im Umfeld der minoischen Villa von Zominthos: Ein Beitrag zur Erforschung der holozänen Landschaftsgeschichte Zentralkretas; mit 21 Tabellen; (mit engl. summary). Zugl.: Heidelberg, Univ., Diss., 2010 Heidelberger geographische Arbeiten 130 Geographisches Inst Heidelberg

Siart C, Eitel B (2013) Santorini tephra on Crete: a mineralogical record of Bronze Age environmental change. In: Meller H, Bertemes F, Bork H-R, Risch R (eds) 1600 - Kultureller Umbruch im Schatten des Thera-Ausbruchs? - 1600 - Cultural change in the shadow of the Thera-Eruption? Landesmuseum für Vorgeschichte, Halle (Saale), pp 77-87
Siddall M, Rohling EJ, Almogi-Labin A, Hemleben C, Meischner D, Schmelzer I, Smeed DA (2003) Sea-level fluctuations during the last glacial cycle. Nature 423:853-858. https://doi.org/10.1038/ nature 01690

Sprafke T, Obreht I (2016) Loess: Rock, sediment or soil - What is missing for its definition? Quatern Int 399:198-207. https://doi. org/10.1016/j.quaint.2015.03.033

Stoops G (2003) Guidelines for analysis and description of soil and regolith thin sections. Soil Science Soc. of America, Madison

Strasser TF, Panagopoulou E, Runnels CN, Murray PM, Thompson N, Karkanas P, McCoy FW, Wegmann KW (2010) Stone Age Seafaring in the Mediterranean: Evidence from the Plakias Region for Lower Paleolithic and Mesolithic Habitation of Crete. Hesperia 79:145-190

Theodorakopoulou K, Pavlopoulos K, Athanassas C, Zacharias N, Bassiakos Y (2012) Sedimentological response to Holocene climate events in the Istron area, Gulf of Mirabello, NE Crete. Quatern Int 266:62-73. https://doi.org/10.1016/j.quaint.2011.05.032

Thiem W (1981) Untersuchungen an Schwemmfächern auf der Peloponnes sowie in Epirus: Ein Beitrag zur Klärung von Geomorphodynamik und Lithostratigraphie des Würm in Griechenland. Würzburger Geographische Arbeiten 53:269-312

Triantaphyllou MV, Antonarakou A, Kouli K, Dimiza M, Kontakiotis G, Papanikolaou MD, Ziveri P, Mortyn PG, Lianou V, Lykousis V, Dermitzakis MD (2009) Late Glacial-Holocene ecostratigraphy of the south-eastern Aegean Sea, based on plankton and pollen assemblages. Geo-Mar Lett 29:249-267. https://doi.org/10.1007/ s00367-009-0139-5

Vandenberghe J, Sun Y, Wang X, Abels HA, Liu X (2018) Grain-size characterization of reworked fine-grained aeolian deposits. Earth Sci Rev 177:43-52. https://doi.org/10.1016/j.earscirev.2017.11. 005

Weiberg E, Unkel I, Kouli K, Holmgren K, Avramidis P, Bonnier A, Dibble F, Finné M, Izdebski A, Katrantsiotis C, Stocker SR, Andwinge M, Baika K, Boyd M, Heymann C (2016) The socioenvironmental history of the Peloponnese during the Holocene: Towards an integrated understanding of the past. Quatern Sci Rev 136:40-65. https://doi.org/10.1016/j.quascirev.2015.10.042

Werner V, Baika K, Tzigounaki A, Reicherter K, Papanikolaou I, Emde K, Fischer P, Vött A (2019) Mid-Holocene tectonic geomorphology of northern Crete deduced from a coastal sedimentary archive near Rethymnon and a Late Bronze Age Santorini tsunamite candidate. Geomorphology 326:167-189. https://doi.org/10.1016/j. geomorph.2018.09.017

Wolf D, Ryborz K, Kolb T, Calvo Zapata R, Sanchez Vizcaino J, Zöller L, Faust D (2019) Origins and genesis of loess deposits in central Spain, as indicated by heavy mineral compositions and grain-size variability. Sedimentology. https://doi.org/10.1111/sed.12539

Yaalon DH (1997) Soils in the Mediterranean region: what makes them different? CATENA 28:157-169. https://doi.org/10.1016/S03418162(96)00035-5

Yassoglou N, Tsadilas C, Kosmas C (2017) The Soils of Greece. Springer International Publishing, Cham, s.1, World Soils Book Series

Zöller L, Nehrig F (2002) Solifluktions-, Löss- und Bodenbildungszyklen seit dem letzten Interglazial im Niederwesterwald. Ber Z Dt Landeskunde 76:115-130

Publisher's Note Springer Nature remains neutral with regard to jurisdictional claims in published maps and institutional affiliations. 